\title{
Role of ambient ammonia in particulate ammonium formation at a rural site in the North China Plain
}

\author{
Zhaoyang Meng ${ }^{1}$, Xiaobin Xu ${ }^{1}$, Weili Lin ${ }^{2, a}$, Baozhu Ge ${ }^{3}$, Yulin Xie ${ }^{4,5}$, Bo Song ${ }^{4}$, Shihui Jia ${ }^{1,6}$, Rui Zhang ${ }^{7,8}$, \\ Wei Peng ${ }^{1}$, Ying Wang ${ }^{1}$, Hongbing Cheng ${ }^{1}$, Wen Yang ${ }^{7}$, and Huarong Zhao ${ }^{1}$ \\ ${ }^{1}$ State Key Laboratory of Severe Weather \& Key Laboratory for Atmospheric Chemistry of CMA, \\ Chinese Academy of Meteorological Sciences, Beijing 100081, China \\ ${ }^{2}$ CMA Meteorological Observation Centre, Beijing 100081, China \\ ${ }^{3}$ State Key Laboratory of Atmospheric Boundary Layer Physics and Atmospheric Chemistry, \\ Institute of Atmospheric Physics, Chinese Academy of Sciences, Beijing 100029, China \\ ${ }^{4}$ University of Science and Technology Beijing, Beijing 100083, China \\ ${ }^{5}$ Baotou Steel Group Mining Research Institute, Baotou 014010, China \\ ${ }^{6}$ South China University of Technology, Guangzhou 510641, China \\ ${ }^{7}$ Chinese Research Academy of Environmental Sciences, Beijing 100012, China \\ ${ }^{8}$ Beijing Municipal Research Institute of Environmental Protection, Beijing 100037, China \\ ${ }^{a}$ now at: College of Life and Environmental Sciences, Minzu University of China, Beijing 100081, China
}

Correspondence: Zhaoyang Meng (mengzy@cma.gov.cn)

Received: 26 February 2017 - Discussion started: 26 April 2017

Revised: 16 November 2017 - Accepted: 20 November 2017 - Published: 8 January 2018

\begin{abstract}
The real-time measurements of $\mathrm{NH}_{3}$ and trace gases were conducted, in conjunction with semi-continuous measurements of water-soluble ions in $\mathrm{PM}_{2.5}$ at a rural site in the North China Plain (NCP) from May to September 2013 in order to better understand chemical characteristics of ammonia and the impact of secondary ammonium aerosols on formation in the NCP. Extremely high $\mathrm{NH}_{3}$ and $\mathrm{NH}_{4}^{+}$concentrations were observed after a precipitation event within 7-10 days following urea application. Elevated $\mathrm{NH}_{3}$ levels coincided with elevated $\mathrm{NH}_{4}^{+}$, indicating that $\mathrm{NH}_{3}$ likely influenced particulate ammonium mass. For the sampling period, the average conversion / oxidation ratios for $\mathrm{NH}_{4}^{+}$ (NHR), $\mathrm{SO}_{4}^{2-}$ (SOR), and $\mathrm{NO}_{3}^{-}$(NOR) were estimated to be $0.30,0.64$, and 0.24 , respectively. The increased $\mathrm{NH}_{3}$ concentrations, mainly from agricultural activities and regional transport, coincided with the prevailing meteorological conditions. The high $\mathrm{NH}_{3}$ level with NHR of about 0.30 indicates that the emission of $\mathrm{NH}_{3}$ in the NCP is much higher than needed for aerosol acid neutralisation, and $\mathrm{NH}_{3}$ plays an important role in the formation of secondary aerosols as a key neutraliser. The hourly data obtained were used to investigate gas-aerosol partitioning characteristics using the thermody-
\end{abstract}

namic equilibrium model ISORROPIA-II. Modelled $\mathrm{SO}_{4}^{2-}$, $\mathrm{NO}_{3}^{-}$, and $\mathrm{NH}_{3}$ values agree well with the measurements, while the modelled $\mathrm{NH}_{4}^{+}$values largely underestimate the measurements. Our observation and modelling results indicate that strong acids in aerosol are completely neutralised. Additional $\mathrm{NH}_{4}^{+}$exists in aerosol, probably a result of the presence of a substantial amount of oxalic and other diacids.

\section{Introduction}

Ammonia $\left(\mathrm{NH}_{3}\right)$ is a very important alkaline constituent in the atmosphere, plays an important role in atmospheric chemistry and is closely related to ecosystems. $\mathrm{NH}_{3}$ has both direct and indirect impacts on critical environmental issues, including regional fine particles, acid rain, and eutrophication (Roelle and Aneja, 2002; Krupa, 2003; Reche et al., 2015). In addition, $\mathrm{NH}_{3}$ is a key species for neutralising $\mathrm{H}_{2} \mathrm{SO}_{4}$ and $\mathrm{HNO}_{3}$ in the atmosphere and forming $\left(\mathrm{NH}_{4}\right)_{2} \mathrm{SO}_{4}, \mathrm{NH}_{4} \mathrm{HSO}_{4}$, and $\mathrm{NH}_{4} \mathrm{NO}_{3}$ (Erisman and Schaap, 2004; Walker et al., 2004), which are major inorganic components of fine particulate matters and contribute to regional 
haze (Ye et al., 2011; Meng et al., 2014; Wei et al., 2015). Global ammonia emission has more than doubled since preindustrial times, mainly because of agricultural intensification (Galloway et al., 2003). The total ammonia emission in China in 2006 was estimated to be 16.07 million tonnes (Mt) (Dong et al., 2010). Such high emission makes $\mathrm{NH}_{3}$ one of the key species related to atmospheric environmental problems. Some studies have indicated that reducing $\mathrm{NH}_{3}$ concentrations could be an effective method for alleviating secondary inorganic $\mathrm{PM}_{2.5}$ pollution in China (Cao et al., 2009; Park et al., 2014; Wang et al., 2015; Xu et al., 2017).

As global food production requirements increase, agriculture plays an increasingly important role in local, regional, and global air quality (Walker et al., 2006). The North China Plain (NCP) is a highly populated region with intensive agricultural production as well as heavy industry. The region has been affected by severe haze and photochemical pollution in recent years (Guo et al., 2010; Wang et al., 2010; Luo et al., 2013). Covering only $3.3 \%$ of the national area, the NCP region provides 40 and $25 \%$ of China's wheat and corn production. To sustain such high agricultural productivity, chemical fertilisers have been intensively applied. Less than $30 \%$ efficiency in $\mathrm{N}$ application causes approximately $40 \% \mathrm{~N}$ loss through various routes including the leaching of $\mathrm{NO}_{3}^{-}$and emission of $\mathrm{NH}_{3}, \mathrm{~N}_{2} \mathrm{O}$, and $\mathrm{N}_{2}$ (Zhang et al., 2010). So far, only a few limited studies have paid attention to the impacts of $\mathrm{NH}_{3}$ on air pollution in the NCP region. According to some studies (Dong et al., 2010; Ianniello et al., 2010; Meng et al., 2011, 2015; Shen et al., 2011), the high $\mathrm{NH}_{3}$ emission intensities observed in the NCP have been caused by high fertiliser application rates and numerous intensive livestock farms. However, there were few simultaneous hightime-resolution measurements of $\mathrm{NH}_{3}$ and $\mathrm{NH}_{4}^{+}$in $\mathrm{PM}_{2.5}$ that also investigated the role in fine particulate formation in China. These studies are necessary to improve our understanding of ammonia pollution on regional air quality and of the impact on formation of secondary ammonium aerosols in the NCP.

During May-September 2013, the intensive field measurements of $\mathrm{NH}_{3}$ and other trace gases, water-soluble ions in $\mathrm{PM}_{2.5}$, and meteorological parameters took place at a rural site in the NCP. In this article, we report the results on $\mathrm{NH}_{3}$, trace gases and major water-soluble ions in $\mathrm{PM}_{2.5}$. We discuss temporal variations in and diurnal patterns of $\mathrm{NH}_{3}$ and $\mathrm{NH}_{4}^{+}$. We also show results from thermodynamic equilibrium simulations and compared them with observations.

\section{Description of experiment}

\subsection{Measurement site}

The measurements were performed from May to September 2013 at Gucheng $\left(39^{\circ} 08^{\prime} \mathrm{N}, 115^{\circ} 40^{\prime} \mathrm{E}, 15.2 \mathrm{~m}\right.$ a.s.l. $)$, a rural site in the NCP, which is an Integrated Ecological Meteoro- logical Observation and Experiment Station of the Chinese Academy of Meteorological Sciences. In Fig. 1, the location of the site is shown on the NCP map with the $\mathrm{NH}_{3}$ emission distribution for the year 2012 from the multi-resolution emission inventory of China (http://meicmodel.org/index.html). The measurement site chosen is situated for monitoring regional background concentrations of air pollutants in the North China Plain and has good regional representativeness (Lin et al., 2009). The site is approximately $110 \mathrm{~km}$ southwest of Beijing, $130 \mathrm{~km}$ west of Tianjin, and $160 \mathrm{~km}$ northeast of Shijiazhuang city in Hebei Province. The site is surrounded by farms, dense villages/towns, and the transportation network in the NCP. The main crops in the area surrounding the site are wheat (winter and spring) and corn (summer and fall). The site is influenced by high $\mathrm{NH}_{3}$ emissions from fertiliser use and animal husbandry in the surrounding area. Being in the warm temperate zone, the site has a typical temperate continental monsoon climate. Precipitation occurs mainly between May and August.

\subsection{Sampling and analysis}

Ambient $\mathrm{NH}_{3}$ was measured using an ammonia analyser (DLT-100, Los Gatos Research, USA), which utilises a unique laser absorption technology called off-axis integrated cavity output spectroscopy. The analyser has a precision of $0.2 \mathrm{ppb}$ at a $100 \mathrm{~s}$ average and a maximum drift of $0.2 \mathrm{ppb}$ over $24 \mathrm{~h}$. The response time of the analyser is less than $2 \mathrm{~s}$ (with an optional external N920 vacuum pump). During the campaign, $\mathrm{NH}_{3}$ data were recorded at a $100 \mathrm{~s}$ average. In principle, the $\mathrm{NH}_{3}$ analyser does not need external calibration because the measured fractional absorption of light at an ammonia resonant wavelength is an absolute measurement of the ammonia density in the cell (manual of economical ammonia analyser - benchtop model 908-0016, Los Gatos Research). However, we confirmed the good performance of the $\mathrm{NH}_{3}$ analyser using a reference gas mixture $\mathrm{NH}_{3} / \mathrm{N}_{2}$ (Air Liquide, USA) traceable to the US National Institute for Standards and Technology (NIST). The reference gas of $\mathrm{NH}_{3}$ (25.92 ppm with an accuracy of $\pm 2 \%$ ) was diluted to different concentrations using zero air and supplied to the analyser, and a sequence with five points of different $\mathrm{NH}_{3}$ concentrations (including zero and the concentrations ranging from 45 to $180 \mathrm{ppb}$ ) were repeated for several times to check the performance of the analyser.

As shown in Fig. S1 in the Supplement, the analyser rapidly followed changes of the $\mathrm{NH}_{3}$ concentration, produced stable response under stabilised $\mathrm{NH}_{3}$ concentrations, and accurately repeated (within the uncertainty) the supplied $\mathrm{NH}_{3}$ concentrations. During the calibration, it took about 20 min for the instrument to show $90 \%$ of the changes in the $\mathrm{NH}_{3}$ concentrations supplied through an aerosol filter and a PTFE tubing ( $4.8 \mathrm{~mm}$ ID, about $3 \mathrm{~m}$ ). However, these time delays also contained the balance time needed for the calibration system. The lag caused by the tubing and anal- 


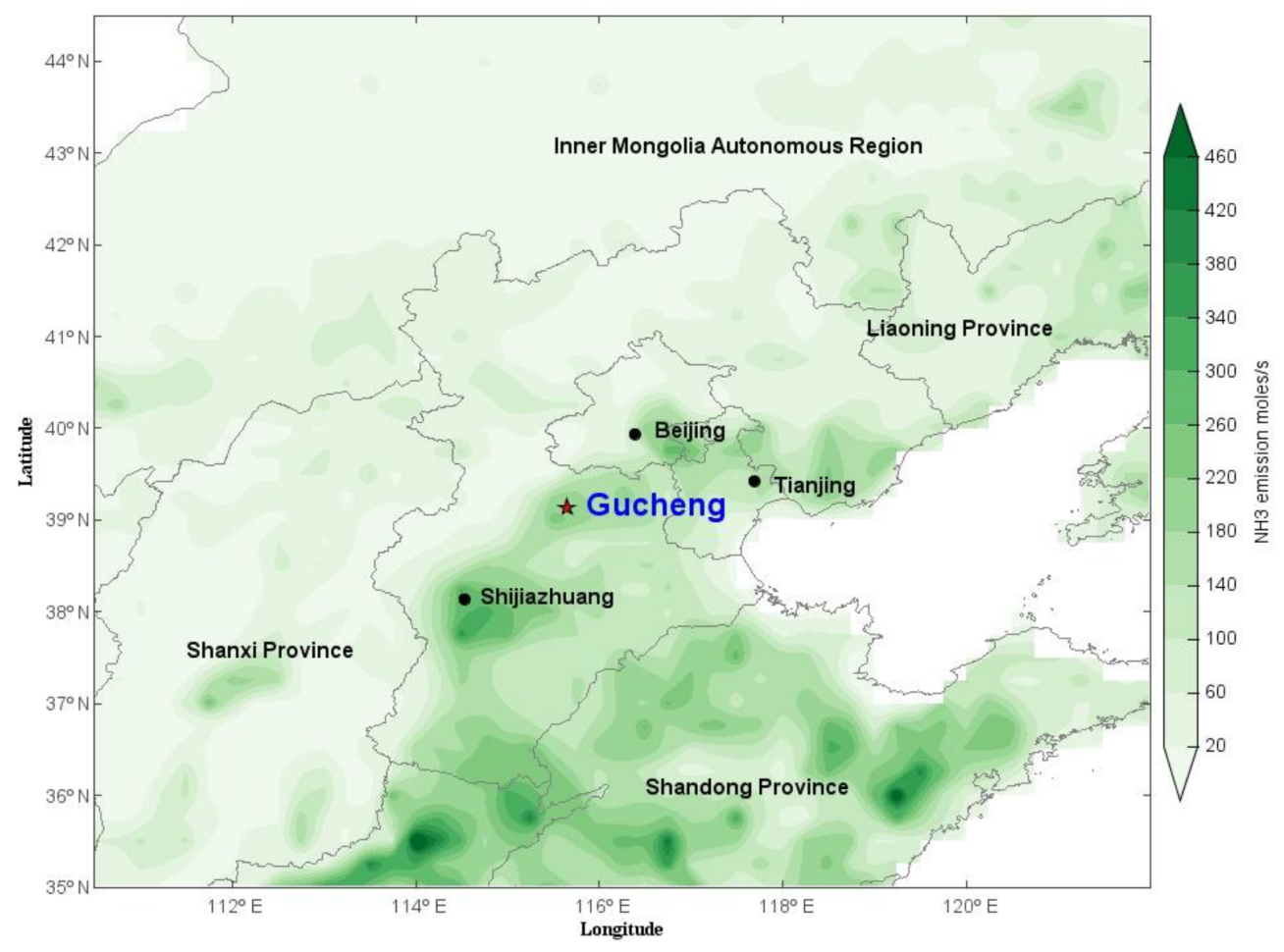

Figure 1. Sampling location in the North China Plain with emission distributions of $\mathrm{NH}_{3}$ for the year 2012 from the multi-resolution emission inventory of China (http://meicmodel.org/index.html).

yser should be much smaller. The $\mathrm{NH}_{3}$ analyser contains an internal inlet aerosol filter, which was cleaned before our campaign. Nevertheless, some very fine particles can deposit on the mirrors of the integrated cavity output spectrometer (ICOS) cell, leading to a gradual decline in reflectivity. However, slight mirror contamination does not cause errors in $\mathrm{NH}_{3}$ measurements because the mirror reflectivity is continually monitored and the measurement is compensated for using the mirror ring-down time. Interferences to $\mathrm{NH}_{3}$ measurements can be from the sample inlets, for example, due to water condensation or adsorption-desorption effects (e.g. Schwab, 2008; Norman et al., 2009). Such interferences were not quantified but reduced as much as possible. PTFE tubing $(4.8 \mathrm{~mm} \mathrm{ID})$, which is one of the well-suited materials for $\mathrm{NH}_{3}$ measurement (Norman et al., 2009), was used to induce ambient air. The length of the tubing was kept as short as possible (about $5 \mathrm{~m}$ ) to limit the residence time to less than $3 \mathrm{~s}$. The aerosol filter at the inlet was changed every 2 weeks. Water condensation was avoided. Nevertheless, we cannot exclude the influence from adsorption and desorption, which can also occur on dry surfaces. However, this influence should be small at our site, where the $\mathrm{NH}_{3}$ concentration is very high, and cause mainly a lag in the recorded $\mathrm{NH}_{3}$ concentration. As hourly averages are used in the work, this lag may not exert a significant influence on our results.

A set of commercial instruments from Thermo Environmental Instruments Inc. were used to measure $\mathrm{O}_{3}$ (TE 49C),
$\mathrm{NO} / \mathrm{NO}_{2} / \mathrm{NO}_{x}$ (TE 42CTL), CO (TE 48C), and $\mathrm{SO}_{2}$ (TE $43 \mathrm{CTL}$ ). All instruments were housed in an air-conditioned room in the observation building at the site. Two parallel inlet tubes (Teflon, $4.8 \mathrm{~mm}$ ID $\times 8 \mathrm{~m}$ length) were shared by the analysers. The height of the inlets was $1.8 \mathrm{~m}$ above the roof of the building and about $8 \mathrm{~m}$ above the ground. The inlet residence time was estimated to be less than $5 \mathrm{~s}$ (Lin et al., 2009). Zero and span checks were performed weekly on the analysers of these trace gases to identify possible analyser malfunctions and zero drifts. Multipoint calibrations of $\mathrm{SO}_{2}, \mathrm{NO}_{x}, \mathrm{CO}$, and $\mathrm{O}_{3}$ analysers were performed on the instruments at approximately 1 month intervals. Measurement records were saved as 1 min averages. After the correction of data on the basis of the multipoint calibrations, hourly average data were calculated and used for the analysis.

An ambient ion monitor (AIM; URG 9000D series, USA) was deployed at the site to measure hourly concentrations of water-soluble inorganic components in $\mathrm{PM}_{2.5}$ during 15 June-11 August 2013. A detailed description of the performance evaluation of the AIM-IC system is reported by Han et al. (2016). Briefly, ambient air was introduced to the AIM with a $2 \mathrm{~m}$ Teflon-coated aluminum pipe and particles larger than $2.5 \mu \mathrm{m}$ were removed by a cyclone at a flow rate of $3 \mathrm{~L} \mathrm{~min}^{-1}$. A liquid diffusion denuder was used to remove the interfering acidic and basic gases, in combination with a steam-jet aerosol collector followed by an aerosol sample collector, until the particles could be injected into the 
ion chromatograph (Hu et al., 2014). The detection limits of $\mathrm{NH}_{4}^{+}, \mathrm{SO}_{4}^{2-}, \mathrm{NO}_{3}^{-}$, and $\mathrm{Cl}^{-}$were $0.05,0.04,0.05$, and $0.01 \mu \mathrm{g} \mathrm{m}^{-3}$, respectively. For the AIM, multipoint calibrations were performed weekly using calibration standard solutions. Acceptable linearity of ions was obtained with an $R^{2}$ of $\geq 0.999$. The flow rate of the AIM was checked weekly at the sample inlet with a certified flow metre. The flow rate of the AIM was kept at $3 \mathrm{~L} \mathrm{~min}^{-1}$ with a standard derivation of $<1 \%$. Hourly data were obtained for the concentrations of water-soluble inorganic ions in summer 2013.

Meteorological parameters were measured at the site. Air temperature and relative humidity $(\mathrm{RH})$ were monitored using a humidity and temperature probe (HMP155, Vaisala, Finland); wind speed and direction were measured using an anemometer (ZQZ-TFD12, Jiangsu Radio Scientific Institute Co. Ltd., China); rainfall was measured using a tilting rain gauge (SL2-1, Tianjin Meteorological Instrument Factory, China). Global radiation observations were made at the site but showed a drift by the end of July 2013. Instead we use the photolysis rate $j \mathrm{NO}_{2}$ observed using a 2-pi-actinicflux spectrograph (CCD type, Meteorologie Consult GmbH, Germany) to indicate the radiation condition for photochemistry. Hourly meteorological data were calculated from the in situ measurements and used in this paper. Planetary boundary layer height (PBLH) values at 14:00 BST (all times in Beijing standard time throughout the paper) were derived from the ERA-Interim data using the bulk Richardson number method (Guo et al., 2016; Miao et al., 2017).

\subsection{Data analysis}

\subsubsection{Chemical conversions of species}

Sulfate and nitrate oxidation ratios (SOR and NOR) are defined as the molar ratio of $\mathrm{SO}_{4}^{2-}$ and $\mathrm{NO}_{3}^{-}$in $\mathrm{PM}_{2.5}$ to the total oxidised $\mathrm{S}$ and $\mathrm{N}$, respectively (Zhang et al., 2011).

$$
\begin{aligned}
\mathrm{SOR} & =\frac{\mathrm{SO}_{4}^{2-}}{\mathrm{SO}_{4}^{2-}+\mathrm{SO}_{2}} \\
\mathrm{NOR} & =\frac{\mathrm{NO}_{3}^{-}}{\mathrm{NO}_{3}^{-}+\mathrm{NO}_{x}}
\end{aligned}
$$

Similarly, the conversion ratio of ammonium (NHR) is expressed in terms of the ratio of ammonium to total ammonia $\left(\mathrm{NH}_{x}\right)$, which could be a measure of the extent of transformation from $\mathrm{NH}_{3}$ to $\mathrm{NH}_{4}^{+}$in areas with major local $\mathrm{NH}_{3}$ sources (Hu et al., 2014).

$\mathrm{NHR}=\frac{\mathrm{NH}_{4}^{+}}{\mathrm{NH}_{4}^{+}+\mathrm{NH}_{3}}$

\subsubsection{Thermodynamic equilibrium}

Thermodynamic gas-aerosol equilibrium characteristics during summer 2013 were examined using the ISORROPIA-
II model (Fountoukis and Nenes, 2007; Fountoukis et al., 2009). ISORROPIA-II is a thermodynamic equilibrium model for inorganic gases and aerosols in the atmosphere (available at http://isorropia.eas.gatech.edu/index.php?title= Main_Page). The concentrations of the measured $\mathrm{NH}_{3}$ and water-soluble ions in $\mathrm{PM}_{2.5}$ were input into the model as total (gas + aerosol) concentrations, along with simultaneously measured relative humidity and temperature data. ISORROPIA-II was run in the forward mode with metastable aerosol-state salt precipitate once the aqueous phase became saturated with respect to salts, which often showed better performance than the stable-state solution (solid + liquid) and was commonly applied in previous $\mathrm{pH}$ predictions (Guo et al., 2015; Bougiatioti et al., 2016; Liu et al., 2017). In this study, the aerosol properties as acidity and the water content of the aerosol are needed to investigate the aerosol acidity characteristics and role of heterogeneous chemistry in nitrate formation. The $\mathrm{pH}$ of aerosol water was calculated using the following equation:

$\mathrm{pH}=-\log _{10} \frac{1000 \mathrm{H}_{\mathrm{air}}^{+}}{\mathrm{AWC}}$

where $\mathrm{H}_{\text {air }}^{+}\left(\mu \mathrm{g} \mathrm{m}^{-3}\right)$ is the ion concentration of the equilibrium particle hydronium and AWC $\left(\mu \mathrm{g} \mathrm{m}^{-3}\right)$ is the aerosol water content from the ISORROPIA-II simulation. The evaluation of the AWC prediction showed a good performance compared with observed particle water (Bian et al., 2014; Guo et al., 2015).

The statistical analysis of the comparison between observations and model predictions was performed by calculating normalised mean bias (NMB) and normalised mean error (NME):

$\mathrm{NMB}=\frac{\sum_{i=1}^{N} M_{i}-O_{i}}{\sum_{i=1}^{N} O_{i}} \times 100 \%$
$\mathrm{NME}=\frac{\sum_{i=1}^{N}\left|M_{i}-O_{i}\right|}{\sum_{i=1}^{N} O_{i}} \times 100 \%$,

where $M_{i}$ and $O_{i}$ are modelled and observed data, respectively. $N$ is the number of data points.

\subsubsection{Trajectory calculation}

The $72 \mathrm{~h}$ backward trajectories were calculated using the HYSPLIT 4.9 model (http://www.arl.noaa.gov/ready/ hysplit4.html). The trajectories terminated at the height of $100 \mathrm{~m}$ above the ground. The trajectory calculations were performed at four times (00:00, 06:00, 12:00, and 18:00 UTC) per day in summer 2013. Individual back trajectories were grouped into five clusters. The number of clusters is identified according to the changes in total spatial variance (TSV). Five is chosen as the final number of clusters considering optimum separation of trajectories (larger number of clusters) and simplicity of display (lower number of cluster). 
The corresponding concentrations of trace gases and watersoluble ions were averaged over the period of $3 \mathrm{~h}$ ahead and after the arrival time for each backward trajectory for further analysis.

\section{Results and discussion}

\subsection{Overview of concentration levels of measured species}

During 15 May-25 September 2013, the average concentrations (ranges) of $\mathrm{NH}_{3}, \mathrm{SO}_{2}$, and $\mathrm{NO}_{x}$ were $36.2(0.1-862.9$ ), 5.0 (0-86.8), and $15.4(2.7-67.7) \mathrm{ppb}$, respectively. As listed in Table 1, the concentration of $\mathrm{NH}_{3}$ at the NCP rural site was lower than that reported at Asian and African urban sites such as Lahore (Pakistan; Biswas et al., 2008), Colonelganj (India; Behera and Sharma, 2010), and Cairo (Egypt; Hassan et al., 2013) but higher than those from other areas in China, Europe, and North America (Plessow et al., 2005; Yao et al., 2006; Lin et al., 2006; Walker et al., 2006; Hu et al., 2008; Meng et al., 2011, 2014; Shen et al., 2011; Schaap et al., 2011; Makkonen et al., 2012; Behera et al., 2013; Gong et al., 2013; Li et al., 2014). For example, the $\mathrm{NH}_{3}$ at the NCP rural site was higher than that found at the Shangdianzi regional background station in the NCP (Meng et al., 2011), Lin'an regional background station in the Yangtze River Delta (YRD) in eastern China (Meng et al., 2014), and the rural site in Beijing (Shen et al., 2011). The relatively high concentrations of $\mathrm{NH}_{3}$ observed in this study were attributed to agricultural activities involving fertiliser use, vegetation, livestock, and human excrement and waste disposal in the surrounding region.

According to an inventory study (Zhang et al., 2010), the total agricultural $\mathrm{NH}_{3}-\mathrm{N}$ emission in 2004 in the $\mathrm{NCP}$ was $3071 \mathrm{kt} \mathrm{yr}^{-1}$, accounting for $27 \%$ of the total emissions in China with $1620 \mathrm{kt} \mathrm{yr}^{-1}$ of $\mathrm{NH}_{3}-\mathrm{N}$ emissions caused by fertiliser applications, which is the largest emission source in China, accounting for more than half of the total agricultural emissions. In recent years, there were a few publications about China's national and regional emission inventories of $\mathrm{NH}_{3}$ (e.g. Zhou et al., 2015; Xu et al., 2015, 2016; Kang et al., 2016). However, these inventories are based on bottom-up studies, subject to substantial uncertainties in spatial and temporal variations in $\mathrm{NH}_{3}$ emissions. Ground-based observations of $\mathrm{NH}_{3}$ have been sparse. Our measurements, together with others, can be used for validating and constraining models that use bottom-up inventories, and hence help to reveal potential bias in $\mathrm{NH}_{3}$ emission inventories.

The observed concentration of $\mathrm{SO}_{2}$ at the NCP rural site was markedly lower than that reported for the same period in 2006-2007 (Lin et al., 2009). Because of a series of emission reduction measures implemented in recent years, $\mathrm{SO}_{2}$ levels have decreased markedly in the NCP (Lin et al., 2011). The average concentration of $\mathrm{NO}_{x}$ was higher than that at the Shangdianzi (Meng et al., 2011) and Lin' an (Meng et al., 2014) regional background stations in the NCP and YRD region of China, which might be due to emissions from agricultural activities and motor vehicle sources (Lei and Wuebbles, 2013; Liu et al., 2013) in the NCP, but it was lower than those at urban sites in India (Behera and Sharma, 2010) and Egypt (Hassan et al., 2013).

The average concentrations (ranges) of $\mathrm{NH}_{4}^{+}, \mathrm{SO}_{4}^{2-}$, and $\mathrm{NO}_{3}^{-}$in $\mathrm{PM}_{2.5}$ were 19.8 (1.07-340.6), 20.5 (3.30-116.9), and $11.3(1.09-109.3) \mu^{-3} \mathrm{~m}^{-3}$, respectively, at the NCP rural site during 15 June-11 August 2013. The average concentration of $\mathrm{NH}_{4}^{+}$in $\mathrm{PM}_{2.5}$ was higher than that observed at the rural or urban sites in the NCP (Meng et al., 2011), the YRD (Meng et al., 2014), Beijing (Shen et al., 2011), Guangzhou (Hu et al., 2008), and Hong Kong (Yao et al., 2006) in China, and is comparable to that at the urban site in India (Behera and Sharma, 2010). The average concentration of $\mathrm{SO}_{4}^{2-}$ in $\mathrm{PM}_{2.5}$ was higher than that at rural sites in the NCP (Meng et al., 2011) and YRD (Meng et al., 2014) in China, but was lower than that observed at rural sites in Guangzhou (Hu et al., 2008) in China as well as urban sites in India (Behera and Sharma, 2010) and Egypt (Hassan et al., 2013). The average concentration of $\mathrm{NO}_{3}^{-}$in $\mathrm{PM}_{2.5}$ was higher than that observed at the rural sites in the YRD and Guangzhou (Hu et al., 2008) in China and lower than that at urban sites in India (Behera and Sharma, 2010) and Pakistan (Biswas et al., 2008). The elevated $\mathrm{NH}_{3}$ and $\mathrm{NH}_{4}^{+}$in $\mathrm{PM}_{2.5}$ concentrations at the NCP rural site demonstrate severe ammonia and fine particulate ammonium pollution in this area.

\subsection{Ambient ammonia}

\subsubsection{Temporal variation in $\mathrm{NH}_{3}$}

The time series of hourly averages of $\mathrm{NH}_{3}$ and other trace gases together with meteorological parameters during 15 May-25 September 2013 at Gucheng are shown in Fig. 2. $\mathrm{NH}_{3}$ concentrations varied considerably during the observation period, ranging from 0.1 to $862.9 \mathrm{ppb}$. The Gucheng station has 8.67 ha of farmland. The observation period was during the wheat harvest and corn planting and growing. Corn was sown and fertilised with about $600 \mathrm{~kg}$ of fertiliser per hectare in late June. On 20 July corn was additionally fertilised with 225 to $300 \mathrm{~kg}$ of urea per hectare. After this fertilisation, there was a rainy period. The $\mathrm{NH}_{3}$ concentration increased rapidly on the seventh day after the urea application on 20 July, peaking during the 27-30 July period (Fig. 2b). The highest hourly value of $\mathrm{NH}_{3}(862.9 \mathrm{ppb})$ was observed at 04:00 local time on 29 July 2013, with the second highest concentration observed at 06:00 on the same day. The extremely high $\mathrm{NH}_{3}$ concentrations were probably caused by intensified soil emissions after rainfall on 26 July, which enhanced the soil moisture. Precipitation and the resulting soil water dynamics are known to strongly affect urea hydrolysis and subsequent $\mathrm{NH}_{3}$ emissions (Reynold and Wolf, 1987; 
Table 1. The comparison of the concentrations of trace gases (ppb) and water-soluble ions in $\mathrm{PM}_{2.5}\left(\mu \mathrm{g} \mathrm{m}{ }^{-3}\right)$ at $\mathrm{Gucheng}$ ith other research.

\begin{tabular}{|c|c|c|c|c|c|c|c|c|c|}
\hline Location & Type & Period & $\mathrm{NH}_{3}$ & $\mathrm{SO}_{2}$ & $\mathrm{NO}_{x}$ & $\mathrm{NH}_{4}^{+}$ & $\mathrm{SO}_{4}^{2-}$ & $\mathrm{NO}_{3}^{-}$ & Reference \\
\hline Gucheng, China & Rural & May-Sep 2013 & $36.2 \pm 56.4$ & $5.0 \pm 6.5$ & $15.4 \pm 9.3$ & $19.8 \pm 33.2$ & $20.5 \pm 13.6$ & $11.3 \pm 9.1$ & This study \\
\hline Shangdianzi, China & Rural & Jun 2008-Dec 2009 & $10.4 \pm 8.1$ & $5.9 \pm 4.6$ & $12.0 \pm 6.8$ & $7.03 \pm 7.76$ & $15.0 \pm 15.7$ & $11.6 \pm 11.4$ & Meng et al. (2011) \\
\hline Beijing, China & Rural & Aug 2006-Jul 2007 & $21.1 \pm 10.5$ & - & $37.8 \pm 11.6$ & $8.8 \pm 6.7$ & $22.4 \pm 16.2$ & $15.1 \pm 11.4$ & Shen et al. (2011) \\
\hline Lin’an, China & Rural & Sep 2009-Dec 2010 & $16.5 \pm 11.2$ & $6.4 \pm 4.2$ & $10.8 \pm 5.2$ & $4.3 \pm 3.5$ & $9.6 \pm 6.1$ & $7.3 \pm 7.5$ & Meng et al. (2014) \\
\hline Guangzhou, China & Rural & Oct-Nov 2004 & 10.5 & 21.2 & - & 9.2 & 24.1 & 7.2 & Hu et al. (2008) \\
\hline Hong Kong, China & Urban & Autumn 2000 & 3 & - & - & 2.4 & 9 & 1 & Yao et al. (2006) \\
\hline Taichung, Taiwan & Urban & Jan-Dec 2002 & $12.2 \pm 4.31$ & - & - & $4.6 \pm 2.0$ & $15 \pm 8.7$ & $6.0 \pm 4.0$ & Lin et al. (2006) \\
\hline Lahore, Pakistan & Urban & Dec 2005-Feb 2006 & 72.1 & 7.4 & - & 16.1 & 19.2 & 18.9 & Biswas et al. (2008) \\
\hline Colonelganj, India & Urban & Summer 2007 & $41.3 \pm 10.5$ & $6.95 \pm 1.99$ & $33.8 \pm 8.56$ & $18.4 \pm 4.7$ & $27.8 \pm 7.6$ & $29.2 \pm 7.5$ & Behera and Sharma (2010) \\
\hline Singapore & Urban & Sep-Nov 2011 & 3.6 & 8.3 & - & 1.76 & 4.41 & 1.29 & Behera et al. (2013) \\
\hline $\begin{array}{l}\text { Oberbärenburg, } \\
\text { Germany }\end{array}$ & Forest & Oct 2001-Apr 2003 & 0.69 & 2.24 & - & 1.55 & 3.07 & 2.22 & Plessow et al. (2005) \\
\hline Netherlands & Rural & Aug 2007 and 2008 & 12.9 & 0.5 & - & 2.4 & 3.1 & 5.9 & Schaap et al. (2011) \\
\hline Helsinki, Finland & Urban & Spring 2010 & $0.40 \pm 0.59$ & $0.29 \pm 0.38$ & - & $0.46 \pm 0.50$ & $1.64 \pm 1.08$ & $1.40 \pm 2.04$ & Makkonen et al. (2012) \\
\hline Cairo, Egypt & Suburban & Summer 2009 & 64.7 & 5.59 & 28.7 & 7.5 & 28 & 4.2 & Hassan et al. (2013) \\
\hline Clinton, NC, USA & Agricultural & Jan 1999-Dec 2000 & 8 & 1.5 & - & 1.76 & 4.22 & 2.05 & Walker et al. (2006) \\
\hline Houston, USA & Urban & Aug 2010 & $3.0 \pm 2.5$ & - & - & $0.5 \pm 1.0$ & $4.5 \pm 4.3$ & $0.3 \pm 0.2$ & Gong et al. (2013) \\
\hline Wyoming, USA & Rural & Dec 2006-Dec 2011 & 0.24 & - & - & 0.26 & 0.48 & 0.32 & Li et al. (2014) \\
\hline
\end{tabular}

Aranibar et al., 2004). The general increase in $\mathrm{NH}_{3}$ emissions was observed when soils with a high moisture content began to dry because of increased diffusion (Burch and Fox, 1989). In addition, high temperatures in summer promote $\mathrm{NH}_{3}$ volatilisation from urea and ammonium dibasic phosphate applied to crops.

The monthly concentration of $\mathrm{NH}_{3}$ depends on its source and meteorological conditions. The monthly average values of $\mathrm{NH}_{3}$ were 28.4, 73.9, 26.4, and $13.5 \mathrm{ppb}$ in June, July, August, and September 2013, respectively. In summer, high temperature promotes the emission of $\mathrm{NH}_{3}$ from natural and fertilised soils as well as vegetation. The concentration of $\mathrm{NH}_{3}$ in July was approximately 5 times higher than that in September, which was influenced by a higher temperature and increased emission rates of local agricultural $\mathrm{NH}_{3}$ sources in July.

$\mathrm{SO}_{2}$ and $\mathrm{NO}_{x}$ are the main precursors of sulfate and nitrate aerosols, and $\mathrm{O}_{3}$ plays an important role in atmospheric chemistry because it acts as a source of $\mathrm{OH}$ radicals through photolysis. The maximum hourly average concentrations of $\mathrm{SO}_{2}$ and $\mathrm{NO}_{x}$ were $86.8 \mathrm{ppb}$ at 00:00 on 21 May and $67.7 \mathrm{ppb}$ at 10:00 on 17 September, respectively. $\mathrm{O}_{3}$ monthly levels were high in June (44.3 ppb) and July (43.7 ppb), with a maximum hourly average value of $149.9 \mathrm{ppb}$ at 15:00 on 25 July 2013.

In contrast to $\mathrm{NH}_{3}$, the highest monthly levels of $\mathrm{SO}_{2}$ (7.0 ppb) and CO (885 ppb) were observed in June, which could be due to the open burning of agricultural waste (straw, cornstalks, and other crops) after harvest in the surrounding area. Previous studies have shown that the burning of crop residue is a crucial source of trace gases such as $\mathrm{NO}_{x}$ and $\mathrm{CO}$ in the NCP during summer (Meng et al., 2009; Lin et al., 2011). The obvious impact of biomass burning was observed during the 16-19 June 2013 period. As CO is mainly emitted from anthropogenic sources such as the burning of biomass, the elevated $\mathrm{CO}$ concentrations $(2529 \mathrm{ppb}$ at 22:00 on 16 and $2488 \mathrm{ppb}$ at 22:00 on 17 June) were observed.
During this pollution episode, the average concentrations of $\mathrm{NH}_{3}, \mathrm{SO}_{2}, \mathrm{NO}_{x}, \mathrm{O}_{3}$, and $\mathrm{CO}$ were 42.6, 7.69, 18.8, 44.0, and $1092 \mathrm{ppb}$, respectively, which were about 1.2-1.5 times higher than the average values for the whole study period. The monthly concentrations of $\mathrm{SO}_{2}, \mathrm{NO}_{x}$, and $\mathrm{CO}$ in July and August decreased compared to those in June. In addition to less influences from biomass burning, meteorological conditions were also in favour of lowering the concentrations of these gases. Figure S2 shows the monthly average diurnal variations in $j \mathrm{NO}_{2}$ and the time series of hourly rainfall during June-August 2013. As can be seen, the average $j \mathrm{NO}_{2}$ increased from June to August, indicating better conditions for photochemical reduction in July and August. There was also a slight increase in rainfall from June to August, which may promote removal of the pollutants. For the secondary pollutant $\mathrm{O}_{3}$, the highest concentration was observed in June. This is consistent with previous results from Gucheng (Lin et al., 2009) and should be related with the annual maximum of background $\mathrm{O}_{3}$ in the NCP, which occurs in June (Ding et al., 2008; Lin et al., 2008).

\subsubsection{Diurnal variations in $\mathrm{NH}_{3}$}

The average diurnal variations in $\mathrm{NH}_{3}$ from June to September 2013 are shown in Fig. 3. As indicated in Fig. 3a, $\mathrm{NH}_{3}$ concentration maxima and minima were observed during 08:00-13:00 and 19:00-23:00, respectively. As for July, $\mathrm{NH}_{3}$ concentrations showed a considerably more pronounced diurnal pattern with a maximum of $59.5 \mathrm{ppb}$ at 08:00. The concentration of $\mathrm{NH}_{3}$ gradually increased during 00:00-03:00, remained relatively constant during 04:00-06:00, and then rapidly increased from 06:00 (beginning just after sunrise). After peaking at approximately 08:00, a decrease was observed until it reached the minimum of $29.8 \mathrm{ppb}$ at 19:00.

The morning peak of $\mathrm{NH}_{3}$ was also observed elsewhere and could have resulted from emissions from fertilised soils and plant stomata, evaporation of dew, human sources, and 

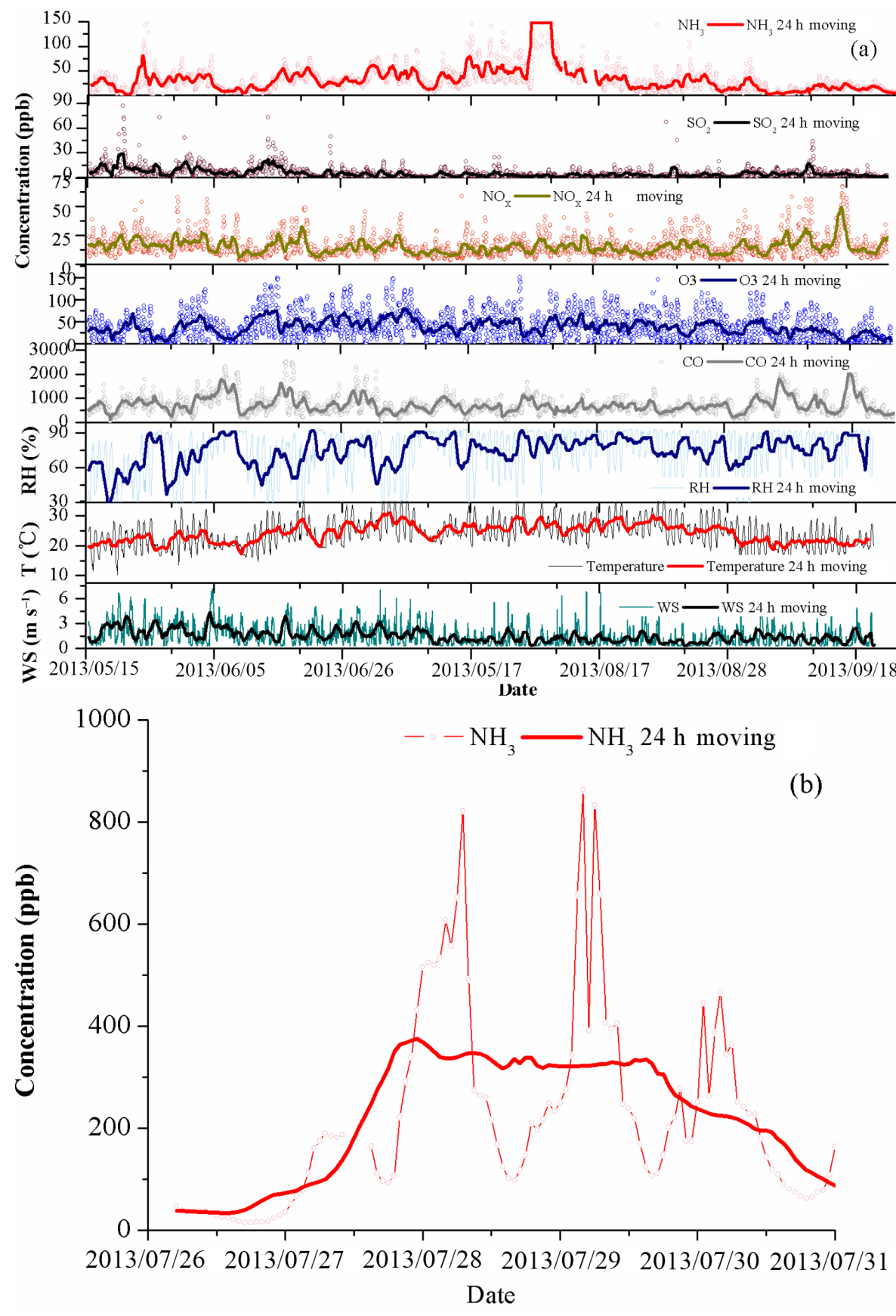

Figure 2. Time series of hourly data of $\mathrm{NH}_{3}$, other trace gases, and meteorological parameters measured during the sampling period (a) and a close-up of the period with extremely high $\mathrm{NH}_{3}$ values during 27-31 July 2013 (b).

mixing down of ammonia from the residual layer (Trebs et al., 2004; Norman et al., 2009; Bash et al., 2010; Ellis et al., 2011). Figure $3 \mathrm{~b}$ reveals that the relative humidity (90-89\%) and temperature $\left(21.5-22.1^{\circ} \mathrm{C}\right)$ remained relatively constant before 06:00 but increased later in the morning. The increasing temperature can heat the Earth's surface and vegetation leaves and reduce the $\mathrm{RH}$, potentially leading to evaporation of $\mathrm{NH}_{3}$ from soil and plants and volatilisation of ammonium aerosol (Trebs et al., 2004; Norman et al., 2009; Ellis et al., 2011), which may increase $\mathrm{NH}_{3}$ concentrations in the morning. When the emission was occurring into a shallow boundary layer, $\mathrm{NH}_{3}$ increase would be more prominent. In addition, the morning rise might also be due to the break-up of the nocturnal boundary layer. During the sampling period, the majority of peaks of ammonia over $50 \mathrm{ppb}$ occurred at night, which were attributed to local emissions such as from agri- 


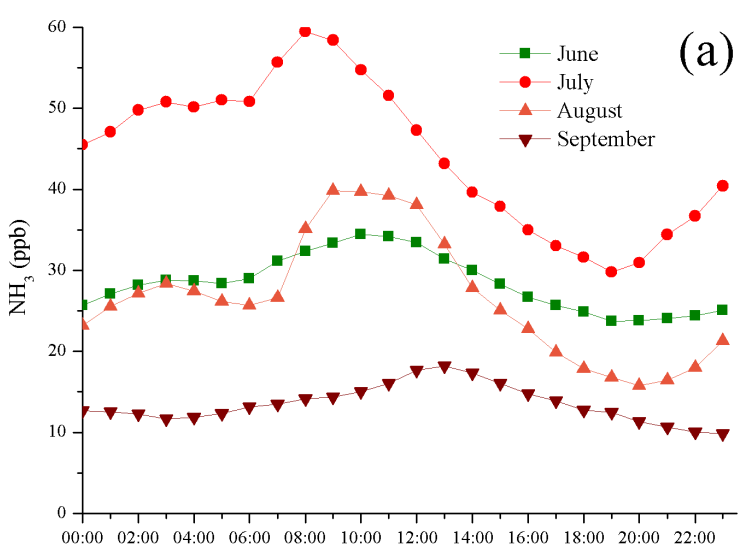

Hour

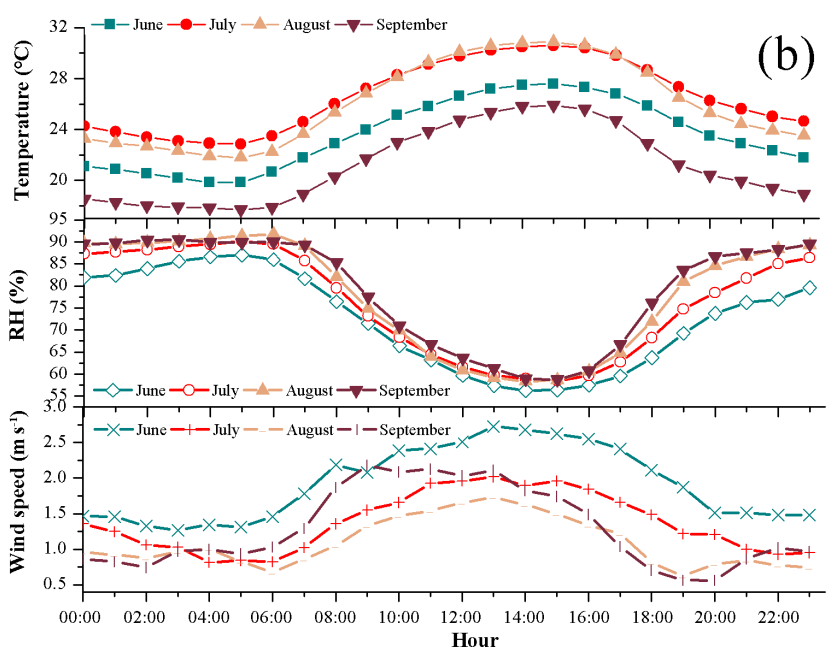

Figure 3. Diurnal variation in $\mathrm{NH}_{3}$ (a) and meteorological parameters (b) during the sampling period.

cultural activity, into a shallow nocturnal boundary layer. It was supposed by Ellis et al. (2011) that the downward mixing of air containing higher $\mathrm{NH}_{3}$ from the residual layer could lead to an increase in surface $\mathrm{NH}_{3}$ after the break-up of the nocturnal boundary layer.

From Fig. 3a, it can be seen that in July the $\mathrm{NH}_{3}$ level was the highest and peaked earliest. One reason for this might be the increased emissions of local agricultural $\mathrm{NH}_{3}$ sources in July compared with those in June, August, and September. On average, the level $\mathrm{NH}_{3}$ in July had a maximum night-time increase (20.0 ppb from 20:00 to 06:00), which is much large than those in June (5.2 ppb), August (9.9 ppb), and September (1.8 ppb). The early morning increase in $\mathrm{NH}_{3}$ in July started from a much higher level than in other months, resulting in the earliest $\mathrm{NH}_{3}$ peak in July.

The Gucheng site is an experiment station for agrometeorological studies. Corn is the main crop in the station area and nearly all the agricultural areas surrounding it. In accordance with the climate in the NCP, corn is planted around the middle of June and grows rapidly in July. Therefore, July is the key period for the application of nitrogen fertilisers like urea. As mentioned above, the urea application at the station on 20 July 2013 and a precipitation process afterwards caused huge $\mathrm{NH}_{3}$ spikes during the end of July (Fig. 2b). In addition, the highest night-time temperature in July (Fig. 3b) could promote the soil emission of $\mathrm{NH}_{3}$, and the relatively lower wind speed (Fig. 3b) and lower PBLH (Fig. S3) in July were in favour of the accumulation of $\mathrm{NH}_{3}$ in surface air.

In summary, ambient $\mathrm{NH}_{3}$ at Gucheng showed interesting diurnal cycles, which look significantly different in different summer months. We believe the interplay of some processes, such as emissions from agricultural sources, meteorological conditions (temperature, relativity humidity, wind speed, PBLH, etc.), and chemical conversion, are important in the determination of levels and diurnal patterns of $\mathrm{NH}_{3}$ at the site. Are all of these processes important in the morning variation in $\mathrm{NH}_{3}$ or not? How important are they? What makes the difference in the peaking time and concentration of $\mathrm{NH}_{3}$ in different months? These are questions to be answered in the future.

\subsection{Ambient ammonium aerosol}

Secondary inorganic aerosols form from gas-phase precursors, which are mostly from anthropogenic activities such as industrial, agricultural, and motor vehicle emissions. Therefore, the major precursors $\left(\mathrm{NH}_{3}, \mathrm{SO}_{2}\right.$, and $\left.\mathrm{NO}_{x}\right)$ are responsible for the formation of particulate ammonium, sulfate, and nitrate.

The hourly $\mathrm{NH}_{4}^{+}$concentrations during 15 June-11 August 2013 ranged from 1.07 to $340.6 \mu \mathrm{g} \mathrm{m}^{-3}$, with an average concentration of $19.8 \mu \mathrm{g} \mathrm{m}^{-3}$. The highest monthly level of $\mathrm{NH}_{4}^{+}$appeared in July and the lowest level appeared in June 2013. Similar to $\mathrm{NH}_{3}$, the concentration of $\mathrm{NH}_{4}^{+}$also increased sharply after urea fertilisation, with the highest value (340.6 $\mu \mathrm{g} \mathrm{m}^{-3}$ ) observed at 09:00 on 28 July 2013. The temporal variations in $\mathrm{NH}_{4}^{+}$basically coincided with $\mathrm{SO}_{4}^{2-}$ and $\mathrm{NO}_{3}^{-}$(discussed in Sect. 3.6), reflecting that $\mathrm{NH}_{4}^{+}$largely originated from the neutralisation between $\mathrm{NH}_{3}$ and acidic species.

The highest hourly $\mathrm{SO}_{4}^{2-}$ concentration $\left(116.9 \mu \mathrm{g} \mathrm{m}^{-3}\right)$ was observed at 10:00 on 9 July and the second highest value was $111.4 \mu \mathrm{g} \mathrm{m}^{-3}$ at 18:00 on 6 August 2013, with an average concentration of $20.5 \pm 13.6 \mu \mathrm{g} \mathrm{m}^{-3}$. Despite the lower concentrations of $\mathrm{SO}_{2}$, higher $\mathrm{SO}_{4}^{2-}$ concentrations in summer were attributed to the higher temperature, $\mathrm{O}_{3}$ concentration, and solar radiation, which increase photochemical activities, atmospheric oxidation, and conversion of $\mathrm{SO}_{2}$ to $\mathrm{SO}_{4}^{2-}$. The average concentration of $\mathrm{NO}_{3}^{-}$in $\mathrm{PM}_{2.5}$ was $11.3 \pm 9.1 \mu \mathrm{g} \mathrm{m}^{-3}$. The highest value of $109.3 \mu \mathrm{g} \mathrm{m}^{-3}$ was observed at 14:00 on 22 June 2013 at the highest RH (93\%) and AWC $\left(910 \mu \mathrm{g} \mathrm{m}^{-3}\right)$. The high RH conditions in summer might dissolve a significant fraction of $\mathrm{HNO}_{3}$ and $\mathrm{NH}_{3}$ in humid particles, therefore increasing the concentrations of $\mathrm{NO}_{3}^{-}$and $\mathrm{NH}_{4}^{+}$in the atmosphere (Krupa, 2003; Trebs et al., 


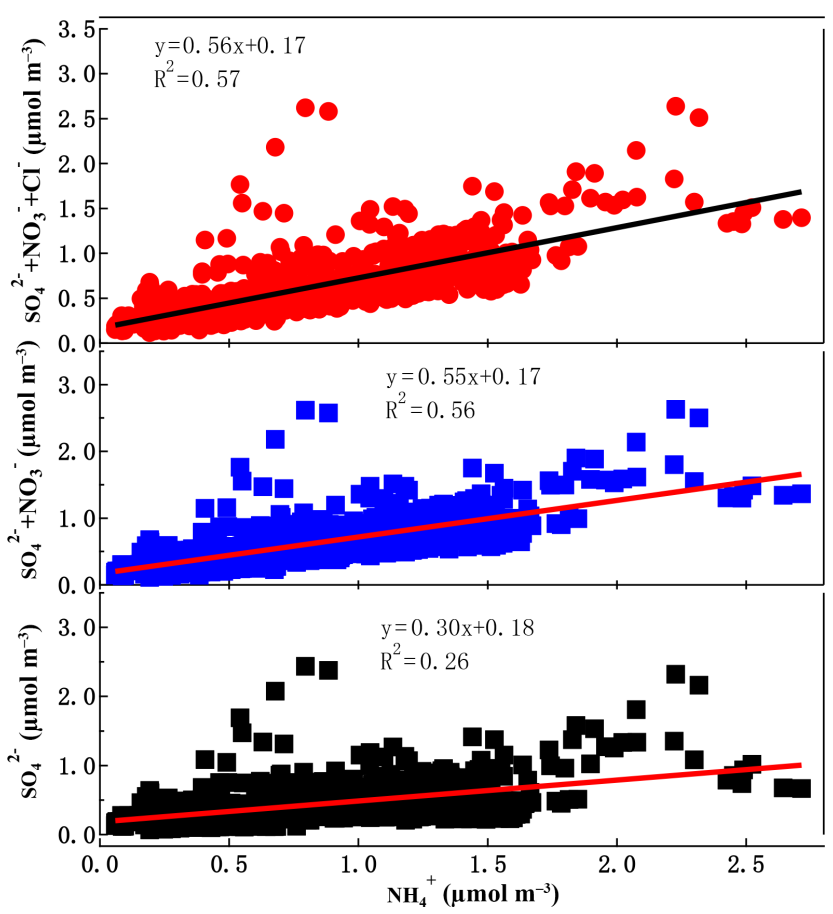

Figure 4. Correlation of observed $\mathrm{NH}_{4}^{+}$with observed $\mathrm{SO}_{4}^{2-}$, $\mathrm{SO}_{4}^{2-}+\mathrm{NO}_{3}^{-}$, and $\mathrm{SO}_{4}^{2-}+\mathrm{NO}_{3}^{-}+\mathrm{Cl}^{-}$.

2004; Ianniello et al., 2010). The high $\mathrm{NO}_{3}^{-}$concentrations were also mostly associated with large AWC, which indicates the importance of heterogeneous hydrolysis in the production of nitrate (Pathak et al., 2009). Conversely, $\mathrm{NH}_{3}$ more efficiently in reacted with $\mathrm{SO}_{2}$ in summer to form $\left(\mathrm{NH}_{4}\right)_{2} \mathrm{SO}_{4}$.

Figure 4 shows correlations of observed $\mathrm{NH}_{4}^{+}$ with the sum of observed $\mathrm{SO}_{4}^{2-}, \mathrm{SO}_{4}^{2-}+\mathrm{NO}_{3}^{-}$, and $\mathrm{SO}_{4}^{2-}+\mathrm{NO}_{3}^{-}+\mathrm{Cl}^{-}$. Although all the correlations are relatively high, the slopes of the regression lines are far from unity. This cannot be due to bias in measurements. The major ion balance shows a ratio of $1.05: 1.0$ for cation : anion. The slope is 0.56 when all three strong acids are considered, suggesting that the neutralisation of the strong acids explains $56 \%$ of the observed $\mathrm{NH}_{4}^{+}$. In other words, nearly $44 \%$ of the observed $\mathrm{NH}_{4}^{+}$was due to the presence of other acids in aerosol particles.

\subsection{Results from thermodynamic equilibrium simulation}

We have used the thermodynamic equilibrium model ISORROPIA-II to investigate gas-aerosol partitioning characteristics. The model outputs include equilibrium $\mathrm{SO}_{4}^{2-}$, $\mathrm{NO}_{3}^{-}, \mathrm{NH}_{3}, \mathrm{NH}_{4}^{+}, \mathrm{H}_{\text {air }}^{+}, \mathrm{HNO}_{3}$, and AWC. As shown in Fig. 5, the modelled $\mathrm{SO}_{4}^{2-}, \mathrm{NO}_{3}^{-}$, and $\mathrm{NH}_{3}$ are highly correlated with the corresponding measurements, with the slopes of regression lines being $0.99,1.01$, and 1.13 for $\mathrm{SO}_{4}^{2-}$, $\mathrm{NO}_{3}^{-}$, and $\mathrm{NH}_{3}$, respectively. The correlation between mod-
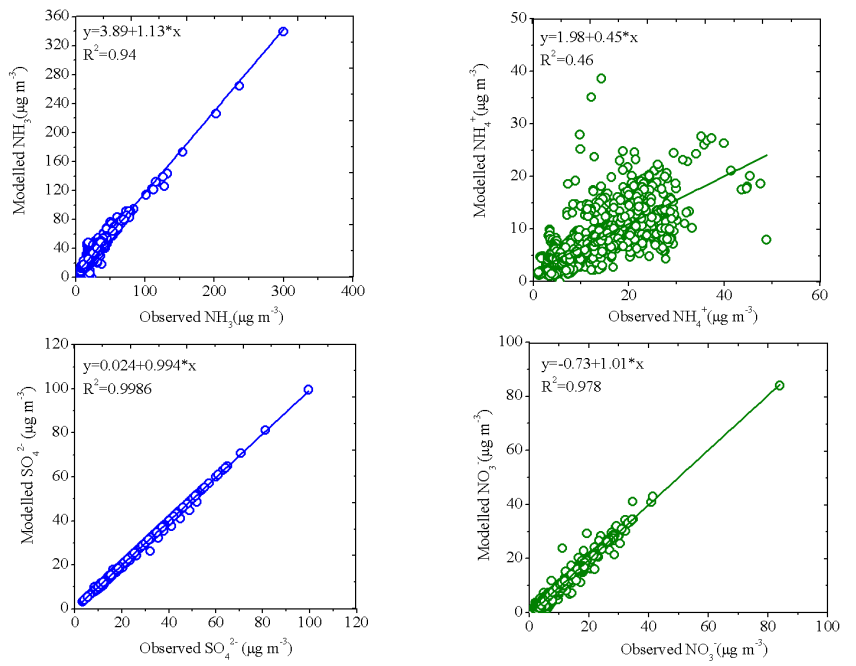

Figure 5. Observed and modelled concentrations of $\mathrm{NH}_{3}, \mathrm{NH}_{4}^{+}$, $\mathrm{SO}_{4}^{2-}$, and $\mathrm{NO}_{3}^{-}$in summer 2013.

elled and observed $\mathrm{NH}_{4}^{+}$is comparably poor but still significant $\left(R^{2}=0.46, P<0.01\right)$, with a slope of 0.45 . The modelled $\mathrm{SO}_{4}^{2-}$ and $\mathrm{NO}_{3}^{-}$agree nearly perfectly with the measurements, while the modelled $\mathrm{NH}_{3}$ and $\mathrm{NH}_{4}^{+}$show a slight overestimation and a large underestimation of the respective measurements. Considering the unbalance between observed $\mathrm{NH}_{4}^{+}$and the sum of observed $\mathrm{SO}_{4}^{2-}+\mathrm{NO}_{3}^{-}+\mathrm{Cl}^{-}$ (see Fig. 4), we believe that other acids in aerosol particles are important in the conversion of $\mathrm{NH}_{3}$ to $\mathrm{NH}_{4}^{+}$. These other acids may be oxalic acid and other dicarboxylic acids. Although we did not measure organic acids in aerosol, the presence of oxalic acid and other low-molecular-weight dicarboxylic acids in aerosols is often reported (e.g. Hsieh et al., 2007; Kawamura et al., 2010, 2013; Sauerwein and Chan, 2017). There is no doubt that there is a significant amount of dicarboxylic acid over the NCP particularly during summer (Kawamura et al., 2013). Therefore, it is highly possible that neutralising dicarboxylic acids in aerosol particles contributed significantly to the conversion of ammonia to ammonium. The presence of a significant amount of dicarboxylic acid can explain the substantial underestimate of $\mathrm{NH}_{4}^{+}$and slight overestimate of $\mathrm{NH}_{3}$ by the model well as the model simulations did not include organics, which were not observed. The low slope $(0.45)$ of the regression line for modelled and observed $\mathrm{NH}_{4}^{+}$implies that organic diacids contributed at least half to the conversion of ammonia to ammonium. Since more $\mathrm{NH}_{4}^{+}$existed in aerosol than was required for neutralising inorganic acids, the ISORROPIA model simulated higher equilibrium $\mathrm{NH}_{3}$ than observed, leading to an overestimate of $\mathrm{NH}_{3}$.

Comparisons between the measurements and the modelled values give a positive $\mathrm{NMB}$ for $\mathrm{NH}_{3}(26.9 \%)$ and a negative $\mathrm{NMB}$ for $\mathrm{SO}_{4}^{2-}(-0.5 \%), \mathrm{NO}_{3}^{-}(-12.5 \%)$, and $\mathrm{NH}_{4}^{+}$ 
$(-32.6 \%)$. NME gives an estimation of overall discrepancy between measurement and model (Sudheer and Rengarajan, 2015). The NME values for the model-observation comparison of $\mathrm{NH}_{3}, \mathrm{SO}_{4}^{2-}, \mathrm{NO}_{3}^{-}$, and $\mathrm{NH}_{4}^{+}$are 31.6, 0.9, 14.8, and $45.8 \%$, respectively. These results indicate that the model simulated $\mathrm{SO}_{4}^{2-}$ and $\mathrm{NO}_{3}^{-}$well but over-predicted $\mathrm{NH}_{3}$ and under-predicted $\mathrm{NH}_{4}^{+}$by around $30 \%$, mainly because of the neglect of organics. Therefore, organics should be observed and included in the model simulations in future studies to better investigate aerosol components and gas-to-aerosol conversion.

The average concentration of simulated $\mathrm{HNO}_{3}$ was $0.7 \mu \mathrm{g} \mathrm{m}^{-3}$, showing a maximum value of $7.41 \mu \mathrm{g} \mathrm{m} \mathrm{m}^{-3}$ at 11:00 on 19 June 2013. The average diurnal variations in $\mathrm{HNO}_{3}$ and $\mathrm{H}_{\text {air }}^{+}$are shown in Fig. 6a. Typical high $\mathrm{HNO}_{3}$ concentrations during daytime and low values at night-time during the observation period are predicted by the model, which is consistent with other studies (Makkonen et al., 2012; Sudheer and Rengarajan, 2015). The diurnal cycle of $\mathrm{H}_{\text {air }}^{+}$is predicted with the highest level around 17:00. The concentrations of $\mathrm{NH}_{3}$ were closely associated with $\mathrm{H}_{\text {air }}^{+}$, and higher $\mathrm{NH}_{3}$ always corresponded to lower $\mathrm{H}_{\text {air }}^{+}$(Liu et al., 2017). The $\mathrm{pH}$ value of aerosol water, estimated based on the simulated results using Eq. (4), are mostly in the range of 2.5-4.5. The fine particles were moderately acidic in summer, with an average $\mathrm{pH}$ value of 3.5 . On average, $\mathrm{pH}$ is over 3.5 during night-time and below 3.5 during daytime (Fig. 6b). Under the medium acidic conditions and high $\mathrm{NH}_{3}$ concentrations, organic acid like diacids are able to react with ammonia to form ammonium. Because we used ISORROPIA-II for inorganic aerosol composition and no organic acid measurements are available, we cannot analyse the role of organic acids in detail, though the model performed quite well (Fig. S4).

\subsection{Relationship between ammonia and ammonium aerosol}

The gas-to-particle conversion between $\mathrm{NH}_{3}$ and $\mathrm{NH}_{4}^{+}$has been reported to be strongly affected by temperature, $\mathrm{RH}$, radiation conditions, the concentration of primary acid gas, and other factors. In this study, $\mathrm{NH}_{4}^{+}$concentrations correlated significantly and positively with $\mathrm{NH}_{3}$, with a correlation coefficient of 0.78 and a slope of 1.48 (Fig. $7 \mathrm{a}, n=915$, $P<0.01$ ), suggesting that $\mathrm{NH}_{3}$ played an important precursor role in $\mathrm{NH}_{4}^{+}$in $\mathrm{PM}_{2.5}$ formation.

The ratio of $\mathrm{NH}_{3}$ to $\mathrm{NH}_{x}\left(\mathrm{NH}_{3}+\mathrm{NH}_{4}^{+}\right)$has been used to identify the source of $\mathrm{NH}_{x}$ and the relative contribution of $\mathrm{NH}_{3}$ to $\mathrm{NH}_{x}$ deposition (Lefer et al., 1999; Walker et al., 2004). A value higher than 0.5 signifies that $\mathrm{NH}_{x}$ is mainly from local $\mathrm{NH}_{3}$ sources and that the dry deposition of $\mathrm{NH}_{3}$ dominates the $\mathrm{NH}_{x}$ deposition. Robarge et al. (2002) reported that more than $70 \%$ of $\mathrm{NH}_{x}$ was in the form of $\mathrm{NH}_{3}$ at an agricultural site in the southeastern United States and concluded that given a larger deposition velocity of ammonia compared with that of ammonium, a considerable fraction of $\mathrm{NH}_{x}$ could be deposited locally rather than be transported out of the region. According to hourly average concentrations, the ratio of $\mathrm{NH}_{3} / \mathrm{NH}_{x}$ varied from 0.22 to 0.97 , with a mean ratio of $0.69 \pm 0.14$, suggesting that $\mathrm{NH}_{3}$ remained predominantly in the gas phase rather than the aerosol phase in summer 2013 at Gucheng.

The diurnal changes in gaseous precursors and aerosol species are controlled by emission and deposition processes, horizontal and vertical transport, and gas-particle partitioning. To investigate gas-particle conversion further, diurnal variation in $\mathrm{NH}_{x}$ is shown in Fig. 7b. Between 08:00 and 18:00, a decrease in $\mathrm{NH}_{3}$ would result in an increase in $\mathrm{NH}_{4}^{+}$, which coincided with higher sulfate concentrations. The decrease in gas phase ammonia is likely the result of uptake onto aerosols to form $\left(\mathrm{NH}_{4}\right)_{2} \mathrm{SO}_{4}$. The diurnal variability in $\mathrm{NH}_{x}$ may be controlled by transport and vertical exchange. Between the hours of 08:00 and 18:00, $\mathrm{NH}_{3}$ decreased by $43 \%$ while $\mathrm{NH}_{x}$ decreased by $49 \%$, suggesting that $\mathrm{NH}_{3}$ remained predominantly in the gas phase. Between 19:00 and 07:00, $\mathrm{NH}_{3}$ increased by $42 \%$ and $\mathrm{NH}_{x}$ increased by $51 \%$, indicating that gas-particle partitioning contributes significantly to the decrease in gas-phase ammonia during this time.

\subsubsection{Gas-to-particle conversion ratio of $\mathrm{NH}_{3}$}

The SOR and NOR are defined in literature to investigate $\mathrm{SO}_{4}^{2-}$ and $\mathrm{NO}_{3}^{-}$formation and gas-particle transformation (Zhang et al., 2011). The average values of SOR and NOR were estimated to be 0.64 and 0.24 during the observation period at Gucheng, with SOR and NOR being higher than previous measurements (Zhou et al., 2009; Du et al., 2011; Zhang et al., 2011). Yao et al. (2002) pointed out an SOR lower than 0.10 under conditions of primary source emissions and higher than 0.10 when sulfate was mainly produced through the secondary transformation of $\mathrm{SO}_{2}$ oxidation. The value of SOR reached 0.70 in August 2013, which may be due to the enhanced atmospheric oxidant levels, sufficient ammonia for neutralisation, and higher RH in summer at Gucheng (Tang et al., 2016).

To gain further insight into the transformation of $\mathrm{NH}_{3}$ to $\mathrm{NH}_{4}^{+}$, the conversion ratio of ammonium (NHR) was investigated. NHR is a measure of the extent of transformation from $\mathrm{NH}_{3}$ to $\mathrm{NH}_{4}^{+}$in areas with significant local $\mathrm{NH}_{3}$ sources, although it encompasses both transport and local equilibrium, the latter dominating further downwind from the source. In this study, the average hourly values of NHR ranged from 0.03 to 0.77 , with an average of 0.30 during summer 2013 . The average NHR level in this study was higher than that observed at an urban site in Beijing (Meng et al., 2017), indicating that high $\mathrm{NH}_{3}$ concentrations resulting from agricultural activities had a marked influence on the formation of ammonium. 

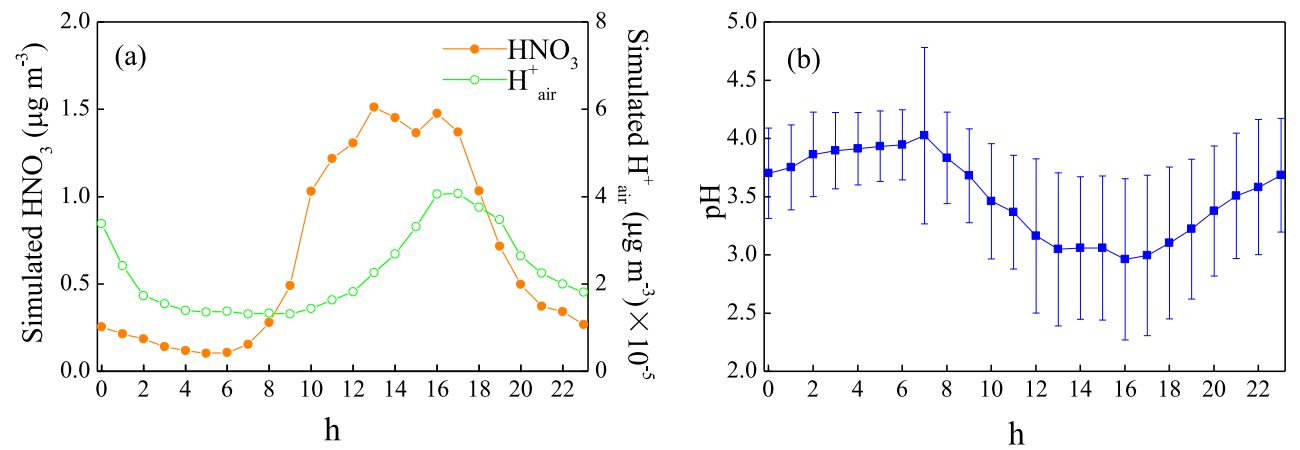

Figure 6. Simulated diurnal variation in $\mathrm{HNO}_{3}$ and $\mathrm{H}_{\text {air }}^{+}$(a) and calculated diurnal variation in the $\mathrm{pH}$ value of aerosol water (b) in summer 2013.
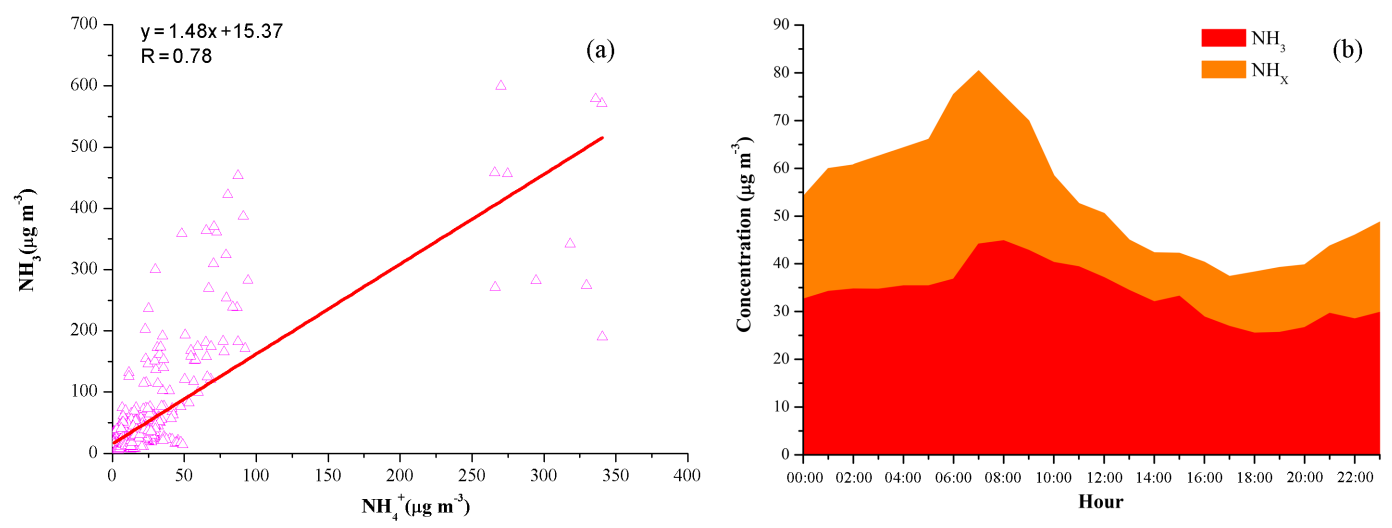

Figure 7. Relationship between $\mathrm{NH}_{3}$ and $\mathrm{NH}_{4}^{+}$(a) and diurnal variation in $\mathrm{NH}_{x}$ (b) in summer 2013.

\subsubsection{Diurnal patterns of NHR, SOR, and NOR}

Figure 8 presents the diurnal patterns of NHR, SOR, NOR, gaseous precursors, major water-soluble ions, and meteorological factors. As a key species contributing to the oxidisation capacity of the atmosphere, $\mathrm{O}_{3}$ can promote $\mathrm{HNO}_{3}$ formation, affecting the conversion ratio of $\mathrm{NH}_{3} . \mathrm{O}_{3}$ exhibited low levels in the morning and enhanced levels in the late afternoon. The lower morning concentrations may be due to the depositional loss of $\mathrm{O}_{3}$ under stable atmospheric conditions in early morning hours, and the higher levels in the afternoon could be due to the photochemical production of $\mathrm{O}_{3}$. The $\mathrm{NH}_{4}^{+}$concentration started to increase from morning, reaching the maximum value $\left(16.1 \mu \mathrm{g} \mathrm{m}^{-3}\right)$ at 18:00, with a diurnal difference of $3.7 \mu \mathrm{g} \mathrm{m}^{-3}$. This diurnal pattern may be due to a combination of high $\mathrm{NH}_{3}$ concentrations, the intense solar radiation at noon, and the high oxidisation capacity of the atmosphere in the afternoon. A clear diurnal cycle of NHR existed, with an amplitude of 0.10 and a peak of 0.35 at 18:00, which is consistent with the higher SOR and RH.

The $\mathrm{SO}_{2}$ concentration showed a maximum at 09:00, with a secondary peak at 22:00. The concentration of $\mathrm{SO}_{4}^{2-}$ showed small peaks at 11:00, 14:00, and 18:00, respectively, but no strong diurnal variation. SOR displayed a diurnal cy- cle with the highest value of 0.74 observed at $05: 00$. It is noted that the SOR was lower during daytime when photochemical reaction is intense. A higher SOR during night-time suggests the importance of dark reactions. $\mathrm{SO}_{2}$ is highly soluble and can easily be absorbed by wet aerosol particles. The high RH at night may have promoted this process.

As for the diurnal cycle of $\mathrm{NO}_{x}$, a peak was observed at 06:00 when the mixing layer was stable, and a broad valley was observed in the daytime, reflecting the influences of a higher mixing layer and stronger photochemical conversion. During the night, $\mathrm{NO}_{x}$ concentrations increased again, resulting in the second maximum at 23:00. $\mathrm{NO}_{3}^{-}$concentrations did not show profound diurnal variations but instead showed slightly higher values during the night time, probably because of the hydrolysis of dinitrogen pentoxide $\left(\mathrm{N}_{2} \mathrm{O}_{5}\right)$ and the condensation of $\mathrm{HNO}_{3}$ under relatively low temperatures. NOR displayed a diurnal pattern with a maximum of 0.28 at 10:00, which was likely related to photochemical reactions under the conditions of high $\mathrm{O}_{3}$ concentrations and $j \mathrm{NO}_{2}$ levels.

Night-time formation, aerosol uptake, and hydrolysis of $\mathrm{N}_{2} \mathrm{O}_{5}$ are highly uncertain as has been pointed out (e.g. Xue et al., 2014). The $\mathrm{NO}_{x}$ concentration during night-time was higher than during daytime, while the $\mathrm{NO}_{3}^{-}$level dur- 


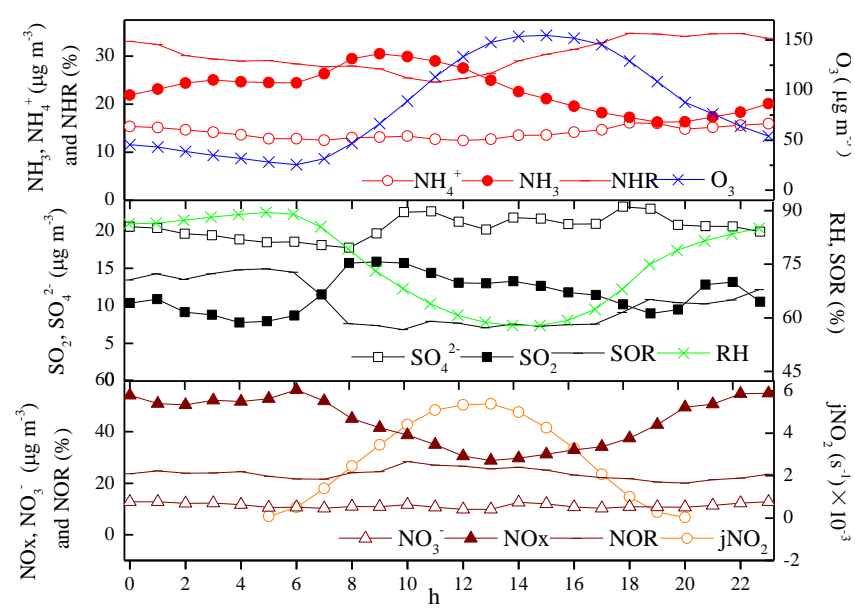

Figure 8. Diurnal variation in NHR, SOR, NOR, gaseous precursors, major water-soluble ions, and meteorological factors in summer 2013.

ing night-time was only slightly higher than that during daytime. By assuming a high aerosol surface-to-mass ratio $\left(33.7 \mathrm{~m}^{2} \mathrm{~g}^{-1}\right.$; Okuda, 2013) and a high uptake coefficient (0.1; Seinfeld and Pandis, 2006), we estimate the night-time $\mathrm{N}_{2} \mathrm{O}_{5}$ under the conditions over our site to be in the range of about $3-10 \mathrm{ppb}$, corresponding to a $\mathrm{HNO}_{3}$ production rate of about $1-3 \mathrm{ppbh}^{-1}$ (or 2.6-7.7 $\mathrm{gg} \mathrm{m}^{-3}$ ). This rate of $\mathrm{HNO}_{3}$ production would cause an obvious night-time production of $\mathrm{NH}_{4}^{+}$. Indeed, we can see increases in the $\mathrm{NH}_{4}^{+}$concentration and NHR at night (Fig. 8). However, a more or less accurate estimate of the relative contribution of the night $\mathrm{N}_{2} \mathrm{O}_{5}$ chemistry to $\mathrm{NH}_{3}$ conversion needs to be made in the future.

\subsection{A case study of a pollution period}

On several days during the study period, very high $\mathrm{NH}_{3}$ and inorganic $\mathrm{PM}_{2.5}$ concentrations were observed. Here we make a case study of a pollution period during 7-11 August 2013. Data on gases, major aerosol ions, and some key meteorological parameters are presented in Fig. 9. Some calculated parameters during this period are given in Fig. S5. As shown in Figs. 9 and S5, there was a sharp increase in $\mathrm{NO}_{x}$ during the night and early morning of 10 August, followed by an increase in $\mathrm{NH}_{3}$ (peak value of $64 \mathrm{ppb}$ ) at 03:00. In the meantime, a large peak of AWC occurred and gaseous $\mathrm{HNO}_{3}$ decreased to nearly zero (Fig. S5), suggesting rapid uptake of wet aerosol. This event caused the first largest peak of $\mathrm{SO}_{4}^{2-}+\mathrm{NO}_{3}^{-}+\mathrm{NH}_{4}^{+}$. After this event, $\mathrm{NH}_{3}$ rose again and reached an even higher peak $(76.3 \mathrm{ppb})$ shortly before noon on 10 August. This peak of $\mathrm{NH}_{3}$ coincided with a valley of $\mathrm{NO}_{x}$, but the $\mathrm{HNO}_{3}$ level increase and $\mathrm{pH}$ value decrease were observed in parallel. A few hours later $\mathrm{SO}_{2}$ showed a large peak and the second largest peak of $\mathrm{SO}_{4}^{2-}+\mathrm{NO}_{3}^{-}+\mathrm{NH}_{4}^{+}$occurred. These data show that a high $\mathrm{NH}_{3}$ concentration was accompanied by a large increase in

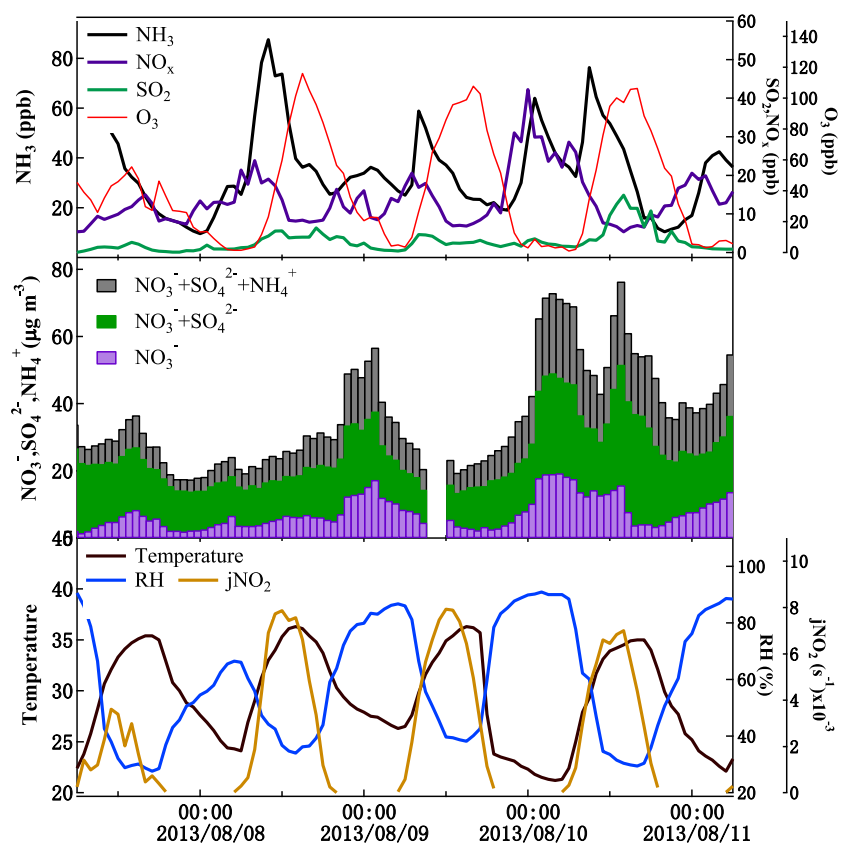

Figure 9. Hourly concentrations of gaseous species, ionic species, and $j \mathrm{NO}_{2}$ measured in the pollution episode during 7-11 August 2013.

concentrations of $\mathrm{SO}_{4}^{2-}, \mathrm{NO}_{3}^{-}$, and $\mathrm{NH}_{4}^{+}$, which is consistent with the view that $\mathrm{NH}_{3}$ plays an important role in particulate matter mass formation and that gas-particle conversion occurred when $\mathrm{NH}_{3}$ was available, though $\mathrm{SO}_{4}^{2-}$ partitions to the aerosol phase impact $\mathrm{NH}_{3}$ level less (Gong et al., 2013).

The secondary ion concentrations had similar temporal distributions with slow accumulation and relatively rapid clearing under favourable meteorological conditions. There was a good correlation between $\mathrm{NH}_{3}$ and $\mathrm{NH}_{4}^{+}, \mathrm{SO}_{4}^{2-}$, and $\mathrm{NO}_{3}^{-}(R=0.33,0.27$, and 0.49 , respectively, with $P<0.01)$. However, there was also a situation in which high $\mathrm{NH}_{3}$ was not associated with high $\mathrm{SO}_{4}^{2-}+\mathrm{NO}_{3}^{-}+\mathrm{NH}_{4}^{+}$, as indicated by the data around noon of 8 August (Fig. 9). During this case, AWC was extremely low and RH was around $40 \%$. These conditions do not favour heterogeneous reactions.

During 7-11 August 2013, the relationships of the observed $\mathrm{NH}_{4}^{+}$versus those of $\mathrm{SO}_{4}^{2-}$, the sum of $\mathrm{SO}_{4}^{2-}$ and $\mathrm{NO}_{3}^{-}$, and the sum of $\mathrm{SO}_{4}^{2-}, \mathrm{NO}_{3}^{-}$, and $\mathrm{Cl}^{-}$are presented in Fig. 10. It is known that $\left(\mathrm{NH}_{4}\right)_{2} \mathrm{SO}_{4}$ is preferentially formed and the least volatile, $\mathrm{NH}_{4} \mathrm{NO}_{3}$ is relatively volatile, and $\mathrm{NH}_{4} \mathrm{Cl}$ is the most volatile. $\mathrm{NH}_{4}^{+}$is thought to be first associated with $\mathrm{SO}_{4}^{2-}$. Afterwards, the excess of $\mathrm{NH}_{4}^{+}$is associated with nitrate and chloride (Meng et al., 2015). It is noted that the correlation of $\mathrm{NH}_{4}^{+}$with the sum of $\mathrm{SO}_{4}^{2-}$ and $\mathrm{NO}_{3}^{-}$ ( $R=0.91$, slope $=1.23$, with $P<0.01$ ) was closer to unity than that of $\mathrm{NH}_{4}^{+}$with $\mathrm{SO}_{4}^{2-}(R=0.80$, slope $=1.65$, with $P<0.01$ ), suggesting that both $\mathrm{SO}_{4}^{2-}$ and $\mathrm{NO}_{3}^{-}$were associated with $\mathrm{NH}_{4}^{+}$. As shown in Fig. 10, sulfate and nitrate were 

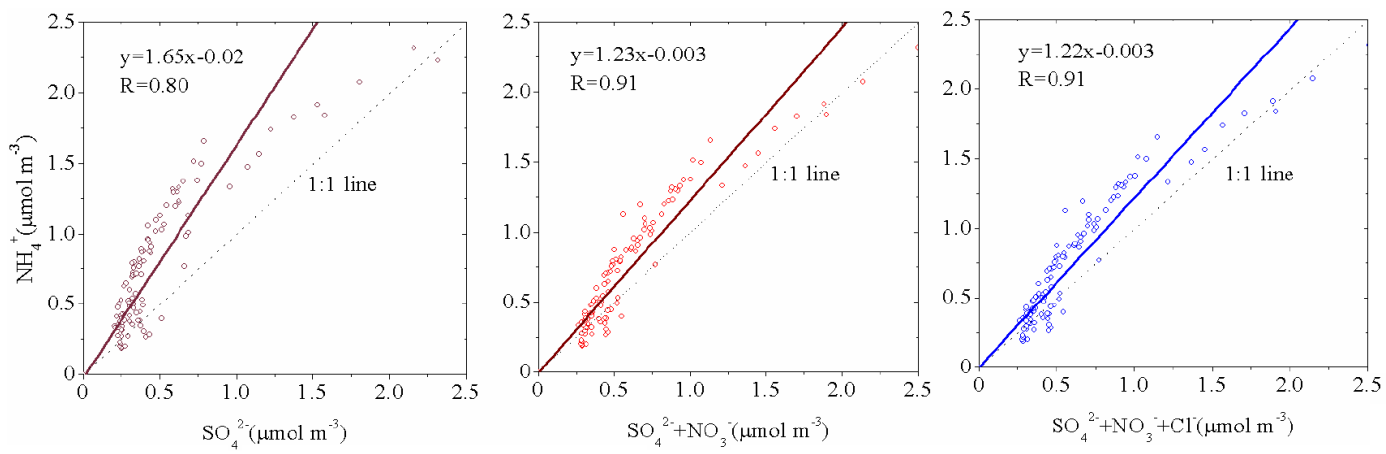

Figure 10. Correlations between $\mathrm{NH}_{4}^{+}$and $\mathrm{SO}_{4}^{2-}, \mathrm{SO}_{4}^{2-}+\mathrm{NO}_{3}^{-}$, and $\mathrm{SO}_{4}^{2-}+\mathrm{NO}_{3}^{-}+\mathrm{Cl}^{-}$during $7-11$ August 2013 .

Table 2. Occurrence frequency and mean values of $\mathrm{NH}_{3}$, other trace gases (ppb), and ionic species in $\mathrm{PM}_{2.5}\left(\mu \mathrm{g} \mathrm{m}{ }^{-3}\right.$ ) for each type of air mass arriving at Gucheng in summer 2013.

\begin{tabular}{lrrrrrrr}
\hline Air mass & Ratio (\%) & $\mathrm{NH}_{3}$ & $\mathrm{SO}_{2}$ & $\mathrm{NO}_{x}$ & $\mathrm{NH}_{4}^{+}$ & $\mathrm{SO}_{4}^{2-}$ & $\mathrm{NO}_{3}^{-}$ \\
\hline Cluster 1 & 15 & 32.8 & 7.9 & 14.0 & 22.3 & 22.6 & 17.7 \\
Cluster 2 & 56 & 48.9 & 3.7 & 14.4 & 17.5 & 22.1 & 10.3 \\
Cluster 3 & 17 & 28.5 & 4.8 & 15.1 & 14.6 & 20.2 & 11.8 \\
Cluster 4 & 10 & 23.4 & 2.4 & 12.8 & 12.9 & 15.3 & 7.2 \\
Cluster 5 & 3 & 16.3 & 0.6 & 9.4 & 7.5 & 8.1 & 5.0 \\
\hline
\end{tabular}

almost completely neutralised with most of the data above the $1: 1$ line. A few scattered data below the $1: 1$ line may be caused by uncertainties in measurements. Little difference was found between the regression slopes of $\mathrm{NH}_{4}^{+}$with the sum of $\mathrm{SO}_{4}^{2-}$ and $\mathrm{NO}_{3}^{-}$and the sum of $\mathrm{SO}_{4}^{2-}, \mathrm{NO}_{3}^{-}$, and $\mathrm{Cl}^{-}$ due to the very low amount of $\mathrm{NH}_{4} \mathrm{Cl}$. In this study, the level of $\mathrm{NH}_{3}$ was high enough to neutralise both $\mathrm{SO}_{4}^{2-}$ and $\mathrm{NO}_{3}^{-}$ and likely to help form $\left(\mathrm{NH}_{4}\right)_{2} \mathrm{SO}_{4}$ and $\mathrm{NH}_{4} \mathrm{NO}_{3}$. In addition to these substances, it is likely that $\mathrm{NH}_{3}$ also reacted with oxalic acid and other dicarboxylic acid to form ammonium oxalate and other organic ammonium aerosols, as discussed above. Data in Fig. 10 seem to be distributed in two groups, with the one (Group 1) covering low to middle levels but exhibiting a larger slope and the other (Group 2) covering middle to high levels but exhibiting a smaller slope. Data in Group 2 were mainly from 10 August 2013 when high $\mathrm{NH}_{4}^{+}$, $\mathrm{SO}_{4}^{2-}$, and $\mathrm{NO}_{3}^{-}$values were observed (see Fig. 9). The difference in slope between the two groups might be caused by different fractions of organic diacids that are considered to convert more ammonia to ammonium. Although no measurements of organic diacids are available to prove this, the significant changes in fractions of organic and inorganic aerosol components are often observed during pollution episodes in China (e.g. Wang et al., 2016). Reduced impact from organic diacids may bring the correlation of $\mathrm{NH}_{4}^{+}$with the sum of $\mathrm{SO}_{4}^{2-}, \mathrm{NO}_{3}^{-}$, and $\mathrm{Cl}^{-}$closer to the $1: 1$ line.

\subsection{Transport effects on local ammonia and ammonium}

The Gucheng site is located in a densely populated rural area in the NCP, and it is influenced by local sources in the surrounding areas and by long-range transport of pollutants from the residential and industrial centres around it. Dependence of the concentrations of $\mathrm{NH}_{3}$ on wind direction at Gucheng is studied to get insight into the distribution of local emission sources around the monitoring site. As shown in Fig. 11, during the sampling period, the prevailing surface winds at Gucheng were northeasterly and southwesterly. High $\mathrm{NH}_{3}$ originated from the southwest sector of the measurement site, which may be due to a local unidentified agricultural or industrial source or transport from the Xushui township, which is approximately $15 \mathrm{~km}$ away from Gucheng. Lower $\mathrm{NH}_{3}$ concentrations were observed under winds from other sectors. Since $\mathrm{NH}_{3}$ is either readily converted to $\mathrm{NH}_{4}^{+}$or subjected to dry deposition, high concentrations are found only close to the surface and near the emission sources. Previous studies have reported an inverse relationship between ground-level concentrations of trace gases, such as ammonia, and wind speed (Robarge et al., 2002; Lin et al., 2011; Meng et al., 2011). Thus, $\mathrm{NH}_{3}$ concentrations might be generally lower at higher wind speeds because of turbulent diffusion.

To identify the impact of long-range air transport on the surface air pollutant levels and secondary ions at Gucheng, 

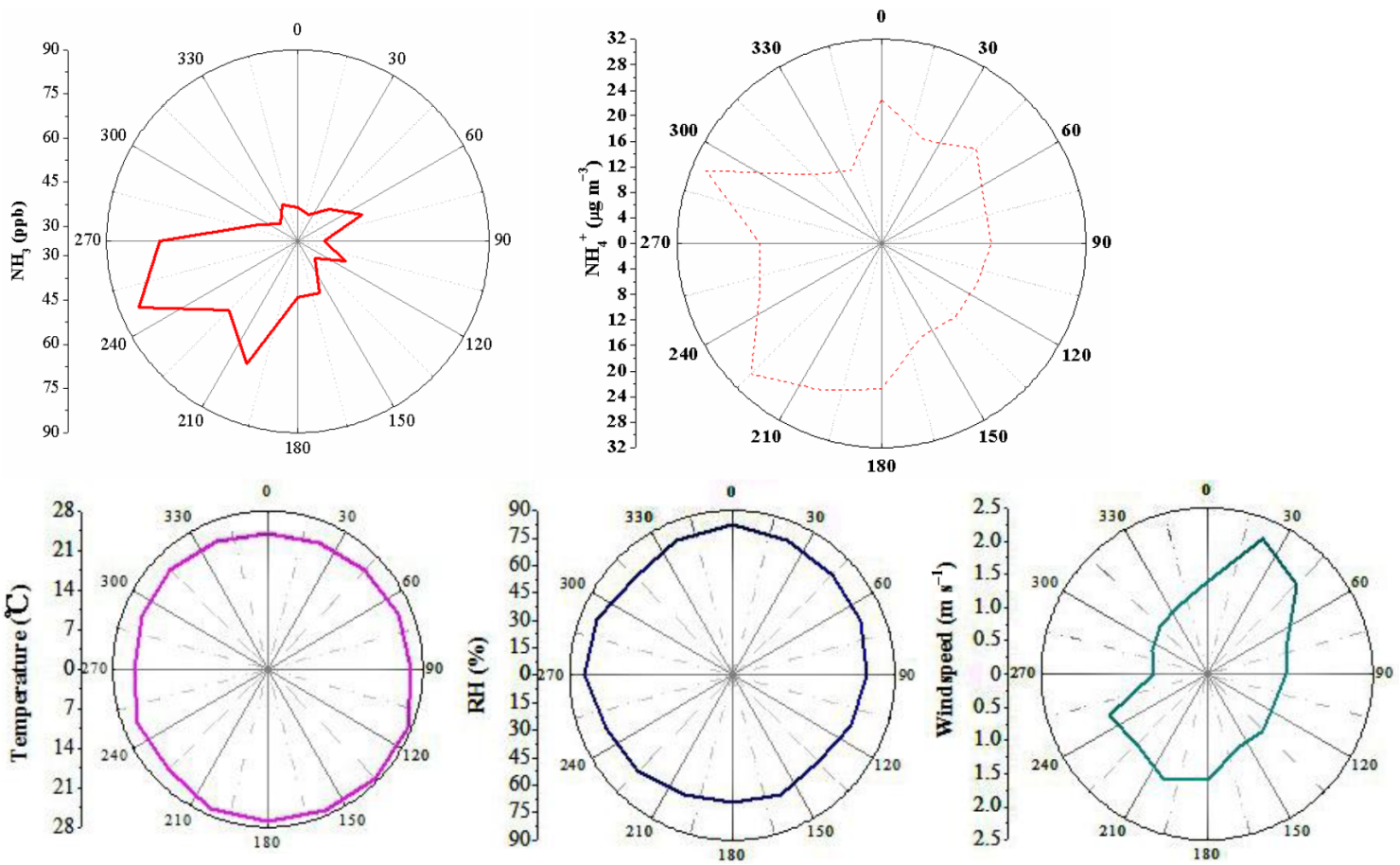

Figure 11. The average $\mathrm{NH}_{3}, \mathrm{NH}_{4}^{+}$, and meteorological data roses in different wind sectors during summer 2013.

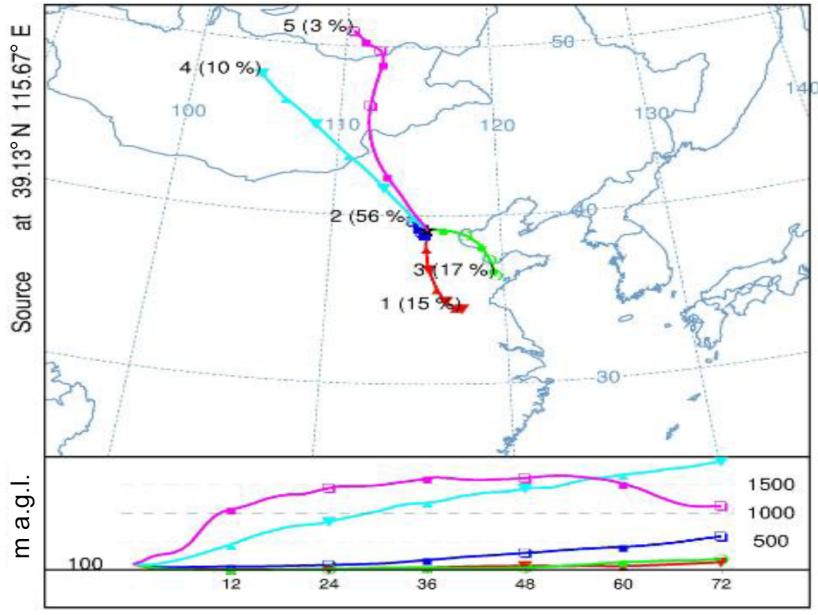

Figure 12. The $72 \mathrm{~h}$ backward trajectories for $100 \mathrm{~m}$ above ground level at Gucheng during the sampling period in 2013.

the $72 \mathrm{~h}$ backward trajectories were calculated using the HYSPLIT 4.9 model.

As can be seen in Fig. 12, Clusters 1, 2, and 3 represent relatively low and slowly moving air parcels, with Cluster 2 coming from northwest areas at the lowest transport height among the five clusters. The air masses of Clusters 1 and 3 originate from the southeast of Gucheng. Clusters 4 and 5 represent air parcels mainly from the far northwest.
The trajectories in Cluster 2 came from the local areas around Gucheng, and it was the most important cluster to the Gucheng site, contributing $56 \%$ to the air masses. Based on the statistics, the number of trajectories in Clusters 1, 2, and 3 account for $88 \%$ of all the trajectories. As more than $80 \%$ of air masses originating from or passing over the NCP region can influence the surface measurements at Gucheng, the observation results at Gucheng can represent the regional state of atmospheric components in the NCP region well.

Since the emission sources of pollutants are unevenly distributed in the areas surrounding the Gucheng site, air masses come from different directions and contain different levels of pollutants. The corresponding mean concentrations of $\mathrm{NH}_{3}$, $\mathrm{SO}_{2}, \mathrm{NO}_{x}, \mathrm{NH}_{4}^{+}, \mathrm{SO}_{4}^{2-}$, and $\mathrm{NO}_{3}^{-}$in $\mathrm{PM}_{2.5}$ in different clusters of backward trajectories are also included in Table 2 in order to characterise the dependence of the pollutant concentrations on air masses.

Large differences in the concentrations of $\mathrm{NH}_{3}, \mathrm{SO}_{2}, \mathrm{NO}_{x}$, $\mathrm{NH}_{4}^{+}, \mathrm{SO}_{4}^{2-}$, and $\mathrm{NO}_{3}^{-}$in $\mathrm{PM}_{2.5}$ existed among the different clusters, with cluster 2 corresponding to the highest $\mathrm{NH}_{3}$ concentration (48.9 ppb) and second highest $\mathrm{NO}_{x}, \mathrm{NH}_{4}^{+}$, and $\mathrm{SO}_{4}^{2-}$ concentrations (14.4 ppb and 17.5 and $22.1 \mu \mathrm{g} \mathrm{m}^{-3}$, respectively).

Cluster 1 corresponds to the highest $\mathrm{SO}_{2}, \mathrm{NH}_{4}^{+}, \mathrm{SO}_{4}^{2-}$, and $\mathrm{NO}_{3}^{-}$concentrations $(7.9 \mathrm{ppb}$ and $22.3,22.6$ and $17.7 \mu \mathrm{g} \mathrm{m}^{-3}$, respectively) and the second highest $\mathrm{NH}_{3}$ level (32.8 ppb). Cluster 3 had the highest $\mathrm{NO}_{x}$ level $(15.1 \mathrm{ppb})$, the second highest $\mathrm{SO}_{2}$ and $\mathrm{NO}_{3}^{-}$levels $(4.8 \mathrm{ppb}$ and $11.8 \mu \mathrm{g} \mathrm{m}^{-3}$, respectively), and had the third highest con- 
centrations of $\mathrm{NH}_{3}, \mathrm{NH}_{4}^{+}$, and $\mathrm{SO}_{4}^{2-}(28.5 \mathrm{ppb}$ and 14.6 and $20.2 \mu \mathrm{g} \mathrm{m}^{-3}$, respectively).

Based on Table 2, the lowest $\mathrm{NH}_{3}, \mathrm{SO}_{2}, \mathrm{NO}_{x}, \mathrm{NH}_{4}^{+}$, $\mathrm{SO}_{4}^{2-}$, and $\mathrm{NO}_{3}^{-}$levels corresponded to Cluster 5, which was expected to bring cleaner air masses to the surface. As demonstrated by backward trajectories, more than half of the air masses during the sampling period from the NCP region contributed to the atmospheric $\mathrm{NH}_{3}$ variations, and both regional sources and long-distance transport from the southeast played important roles in the observed ammonium aerosol at the rural site in the NCP.

\section{Conclusions}

Online measurements of $\mathrm{NH}_{3}$, trace gases, and water-soluble ions in $\mathrm{PM}_{2.5}$ were conducted during May-September 2013 at a rural site in the NCP, where a large amount of ammonia was emitted because of agricultural activities. The average concentrations (ranges) of $\mathrm{NH}_{3}$ and $\mathrm{NH}_{4}^{+}$in $\mathrm{PM}_{2.5}$ were 36.2 (0.1-862.9) ppb during 15 May-25 September 2013, and 19.8 (1.07-340.6) $\mu \mathrm{g} \mathrm{m}^{-3}$ during 15 June-11 August 2013, respectively; these are considerably higher than those reported at other sites in China, Europe, and North America. Extremely high $\mathrm{NH}_{3}$ and $\mathrm{NH}_{4}^{+}$concentrations were observed, which was attributed to a high soil moisture level due to rainfall on the days following the urea application. Elevated $\mathrm{NH}_{3}$ levels coincided with elevated $\mathrm{NH}_{4}^{+}$, indicating the contribution of atmospheric $\mathrm{NH}_{3}$ to secondary inorganic aerosols during periods of agricultural activity. $\mathrm{NH}_{3}$ contributed $69 \%$ to the total $\mathrm{NH}_{3}+\mathrm{NH}_{4}^{+}$in summer, suggesting that $\mathrm{NH}_{x}$ remained predominantly in the gas phase rather than the aerosol phase in summer 2013 at Gucheng.

The average conversion/oxidation ratios for $\mathrm{NH}_{4}^{+}$ (NHR), $\mathrm{SO}_{4}^{2-}$ (SOR), and $\mathrm{NO}_{3}^{-}$(NOR) were estimated to be $0.30,0.64$, and 0.24 in summer 2013 , respectively. Results reveal that the concentrations of $\mathrm{NH}_{3}, \mathrm{NH}_{4}^{+}$, and $\mathrm{NHR}$ had clear diurnal variations during the observation period. High $\mathrm{NH}_{3}$ and $\mathrm{NH}_{4}^{+}$were observed during the late night and early morning periods. NHR also showed higher values at night, suggesting the importance of heterogeneous reactions driven by high night-time RH. The hourly data obtained were used to investigate gas-aerosol partitioning characteristics using the thermodynamic equilibrium model ISORROPIAII. Modelled $\mathrm{SO}_{4}^{2-}, \mathrm{NO}_{3}^{-}$, and $\mathrm{NH}_{3}$ values agree well with the measurements, while the modelled $\mathrm{NH}_{4}^{+}$largely underestimates the measurements. Our measurement and modelling results indicate that the strong acids in aerosol particles over the rural site were neutralised well by $\mathrm{NH}_{3}$. Nearly half of the ammonium was not associated with strong acids but probably with oxalic acid and other diacids, which may present under the medium aerosol acidity ( $\mathrm{pH}$ around 3.5).

The back trajectory analysis indicates that the transport from the NCP region contributed $56 \%$ of the air mass with high $\mathrm{NH}_{3}$ levels. Meanwhile, long-distance transport from the southeast accounted for $32 \%$ of the air mass with high $\mathrm{NH}_{4}^{+}, \mathrm{SO}_{4}^{2-}$, and $\mathrm{NO}_{3}^{-}$at the rural site in the NCP.

$\mathrm{NH}_{3}$ is currently not included in China's emission control policies of air pollution precursors, though people have been discussing the necessity of doing so for years. Our findings highlight the important role of $\mathrm{NH}_{3}$ in secondary inorganic and organic aerosol formation. As the emissions and concentration of $\mathrm{NH}_{3}$ in the NCP are much higher than needed for aerosol acid neutralisation, we speculate that a substantial amount of reduction in $\mathrm{NH}_{3}$ emission is required to see its effect on the alleviation of $\mathrm{PM}_{2.5}$ pollution in the NCP. Therefore, further strong reduction of the emissions of primary aerosol, $\mathrm{NH}_{3}, \mathrm{SO}_{2}, \mathrm{NO}_{x}$, and volatile organic compounds is suggested to address the serious occurrence of $\mathrm{PM}_{2.5}$ pollution on the NCP.

Data availability. The data used in this study are available from the corresponding author upon request (mengzy@cma.gov.cn).

Supplement. The supplement related to this article is available online at: https://doi.org/10.5194/acp-18-167-2018-supplement.

Competing interests. The authors declare that they have no conflict of interest.

Acknowledgements. This work was supported by the National Natural Science Foundation of China $(21377165,41330422$, and 21777191), the China Special Fund for Meteorological Research in the Public Interest (GYHY201206015), and the Environmental Protection Public Welfare Scientific Research Project, Ministry of Environmental Protection of the People's Republic of China (grant nos. 201509001, 201509002-04, and 201309009). The authors would like to thank Xiangde $\mathrm{Xu}$ and $\mathrm{Yu}$ Song for their helpful support and suggestions. The authors would like to thank Yaqiang Wang for providing $\mathrm{NH}_{3}$ emission data and Chao He for help with plotting the graphs.

Edited by: Eleanor Browne

Reviewed by: two anonymous referees

\section{References}

Aranibar, J. N., Otter, L., Macko, S. A., Feral, C. J. W., Epstein, H. E., Dowty, P. R., Eckardt, F., Shugart, H. H., and Swap, R. $\mathrm{J}$.: Nitrogen cycling in the soil plant system along a precipitation gradient in the Kalahari sands, Glob. Change Biol., 10, 359-373, 2004.

Bash, J. O., Walker, J. T., Katul, G. G., Jones, M. R., Nemitz, E., and Robarg, W. P.: Estimation of In-Canopy Ammonia Sources and Sinks in a Fertilized Zea mays Field, Environ. Sci. Technol., 44, 1683-1689, 2010. 
Behera, S. N. and Sharma, M.: Investigating the potential role of ammonia in ion chemistry of fine particulate matter formation for an urban environment, Sci. Total Environ., 408, 3569-3575, 2010.

Behera, S. N., Betha, R., and Balasubramanian, R.: Insight into chemical coupling among acidic gases, ammonia and secondary inorganic aerosols, Aerosol Air Qual. Res., 13, 1282-1296, 2013.

Bian, Y. X., Zhao, C. S., Ma, N., Chen, J., and Xu, W. Y.: A study of aerosol liquid water content based on hygroscopicity measurements at high relative humidity in the North China Plain, Atmos. Chem. Phys., 14, 6417-6426, https://doi.org/10.5194/acp14-6417-2014, 2014.

Biswas, K. F., Ghauri, B. M., and Husain, L.: Gaseous and aerosol pollutants during fog and clear episodes in South Asian urban atmosphere, Atmos. Environ., 42, 7775-7785, 2008.

Bougiatioti, A., Bezantakos, S., Stavroulas, I., Kalivitis, N., Kokkalis, P., Biskos, G., Mihalopoulos, N., Papayannis, A., and Nenes, A.: Biomass-burning impact on CCN number, hygroscopicity and cloud formation during summertime in the eastern Mediterranean, Atmos. Chem. Phys., 16, 7389-7409, https://doi.org/10.5194/acp-16-7389-2016, 2016.

Burch, J. A. and Fox, R. H.: The effect of temperature and initial soil moisture content on the volatilization of ammonia from surface applied urea, Soil Sci., 147, 311-318, 1989.

Cao, J. J., Zhang, T., Chow, J. C., Watson, J. G., Wu, F., and Li, H.: Characterization of Atmospheric Ammonia over Xi' an, China, Aerosol Air Qual. Res., 9, 277-289, 2009.

Ding, A. J., Wang, T., Thouret, V., Cammas, J.-P., and Nédélec, P.: Tropospheric ozone climatology over Beijing: analysis of aircraft data from the MOZAIC program, Atmos. Chem. Phys., 8, 1-13, https://doi.org/10.5194/acp-8-1-2008, 2008.

Dong, W., Xing, J., and Wang, S.: Temporal and spatial distribution of anthropogenic ammonia emissions in China: 1994-2006, Environ. Sci., 31, 1457-1463, 2010 (in Chinese).

Du, H. H., Kong, L. D., Cheng, T. T., Chen, J. M., Du, J. F., Li, L., Xia, X. G., Leng, C. P., and Huang, G. H.: Insights into summertime haze pollution events over Shanghai based on online water soluble ionic composition of aerosols, Atmos. Environ., 45, 5131-5137, 2011.

Ellis, R. A., Murphy, J. G., Markovic, M. Z., VandenBoer, T. C., Makar, P. A., Brook, J., and Mihele, C.: The influence of gasparticle partitioning and surface-atmosphere exchange on ammonia during BAQS-Met, Atmos. Chem. Phys., 11, 133-145, https://doi.org/10.5194/acp-11-133-2011, 2011.

Erisman, J. W. and Schaap, M.: The need for ammonia abatement with respect to secondary PM reductions in Europe, Environ. Pollut., 129, 159-163, 2004.

Fountoukis, C. and Nenes, A.: ISORROPIA II: a computationally efficient thermodynamic equilibrium model for $\mathrm{K}^{+}$$\mathrm{Ca}^{2+}-\mathrm{Mg}^{2+}-\mathrm{NH}_{4}^{+}-\mathrm{Na}^{+}-\mathrm{SO}_{4}^{2-}-\mathrm{NO}_{3}^{-}-\mathrm{Cl}^{-}-\mathrm{H}_{2} \mathrm{O}$ aerosols, Atmos. Chem. Phys., 7, 4639-4659, https://doi.org/10.5194/acp-74639-2007, 2007.

Fountoukis, C., Nenes, A., Sullivan, A., Weber, R., Van Reken, T., Fischer, M., Matias, E., Moya, M., Farmer, D., and Cohen, R. C.: Thermodynamic characterization of Mexico City aerosol during MILAGRO 2006, Atmos. Chem. Phys., 9, 2141-2156, https://doi.org/10.5194/acp-9-2141-2009, 2009.
Galloway, J. N., Aber, J. D., Erisman, J. W., Seitzinger, S. P., Howarth, R. W., Cowling, E. B., and Cosby, B. J.: The nitrogen cascade, BioScience, 53, 341-353, 2003.

Gong, L. W., Lewicki, R., Griffin, R. J., Tittel, F. K., Lonsdale, C. R., Stevens, R. G., Pierce, J. R., Malloy, Q. G. J., Travis, S. A., Bobmanuel, L. M., Lefer, B. L., and Flynn, J. H.: Role of atmospheric ammonia in particulate matter formation in Houston during summertime, Atmos. Environ., 77, 893-900, 2013.

Guo, H., Xu, L., Bougiatioti, A., Cerully, K. M., Capps, S. L., Hite Jr., J. R., Carlton, A. G., Lee, S.-H., Bergin, M. H., Ng, N. L., Nenes, A., and Weber, R. J.: Fine-particle water and $\mathrm{pH}$ in the southeastern United States, Atmos. Chem. Phys., 15, 5211-5228, https://doi.org/10.5194/acp-15-5211-2015, 2015.

Guo, J., Miao, Y., Zhang, Y., Liu, H., Li, Z., Zhang, W., He, J., Lou, M., Yan, Y., Bian, L., and Zhai, P.: The climatology of planetary boundary layer height in China derived from radiosonde and reanalysis data, Atmos. Chem. Phys., 16, 13309-13319, https://doi.org/10.5194/acp-16-13309-2016, 2016.

Guo, S., Hu, M., Wang, Z. B., Slanina, J., and Zhao, Y. L.: Sizeresolved aerosol water-soluble ionic compositions in the summer of Beijing: implication of regional secondary formation, Atmos. Chem. Phys., 10, 947-959, https://doi.org/10.5194/acp-10-9472010, 2010.

Han, B., Zhang, R., Yang, W., Bai, Z., Ma, Z., and Zhang, W.: Heavy haze episodes in Beijing during January 2013: inorganic ion chemistry and source analysis using highly time-resolved measurements from an urban site, Sci. Total Environ., 544, 319329, 2016.

Hassan, S. K., El-Abssawy, A. A., and Khoder, M. I.: Characteristics of gas-phase nitric acid and ammonium-nitrate-sulfate aerosol, and their gas-phase precursors in a suburban area in Cairo, Egypt, Atmos. Pollut. Res., 4, 117-129, 2013.

Hsieh, L. Y., Kuo, S. C., Chen, C. L., and Tsai, Y. I.: Origin of lowmolecular-weight dicarboxylic acids and their concentration and size distribution variation in suburban aerosol, Atmos. Environ., 41, 6648-6661, 2007.

Hu, G. Y., Zhang, Y. M., Sun, J. Y., Zhang, L. M., Shen, X. J., Lin, W. L., and Yang, Y.: Variability, formation and acidity of watersoluble ions in $\mathrm{PM}_{2.5}$, in Beijing based on the semi-continuous observations, Atmos. Res., 145-146, 1-11, 2014.

Hu, M., Wu, Z. J., Slanina, J., Lin, P., Liu, S., and Zeng, L. M.: Acidic gases, ammonia and water-soluble ions in $\mathrm{PM}_{2.5}$ at a coastal site in the Pearl River Delta, China, Atmos. Environ., 42, 6310-6320, 2008.

Ianniello, A., Spataro, F., Esposito, G., Allegrini, I., Rantica, E., Ancora, M. P., Hu, M., and Zhu, T.: Occurrence of gas phase ammonia in the area of Beijing (China), Atmos. Chem. Phys., 10, 9487-9503, https://doi.org/10.5194/acp-10-9487-2010, 2010.

Kang, Y., Liu, M., Song, Y., Huang, X., Yao, H., Cai, X., Zhang, H., Kang, L., Liu, X., Yan, X., He, H., Zhang, Q., Shao, M., and Zhu, T.: High-resolution ammonia emissions inventories in China from 1980 to 2012, Atmos. Chem. Phys., 16, 2043-2058, https://doi.org/10.5194/acp-16-2043-2016, 2016.

Kawamura, K., Barrie, L. A., and Desiree, T.-S.: Intercomparison of the measurements of oxalic acid in aerosols by gas chromatography and ion chromatography, Atmos. Environ., 44, 5316-5319, 2010.

Kawamura, K., Tachibana, E., Okuzawa, K., Aggarwal, S. G., Kanaya, Y., and Wang, Z. F.: High abundances of water-soluble 
dicarboxylic acids, ketocarboxylic acids and $\alpha$-dicarbonyls in the mountaintop aerosols over the North China Plain during wheat burning season, Atmos. Chem. Phys., 13, 8285-8302, https://doi.org/10.5194/acp-13-8285-2013, 2013.

Krupa, S. V.: Effects of atmospheric ammonia $\left(\mathrm{NH}_{3}\right)$ on terrestrial vegetation: A review, Environ. Pollut., 124, 179-221, 2003.

Lefer, B., Talbot, R., and Munger, J.: Nitric acid and ammonia at a rural northeastern US site, J. Geophys. Res., 104, 1645-1661, 1999.

Lei, H. and Wuebbles, D. J.: Chemical competition in nitrate and sulfate formations and its effect on air quality, Atmos. Environ., 80, 472-477, 2013.

Li, Y., Schwandner, F. M., Sewell, H. J., Zivkovich, A., Tigges, M., Raja, S., Holcomb, S., Molenar, J. V., Sherman, L., Archuleta, C., Lee, T., and Collett, J. L.: Observations of ammonia, nitric acid, and fine particles in a rural gas production region, Atmos. Environ., 83, 80-89, 2014.

Lin, W., Xu, X., Zhang, X., and Tang, J.: Contributions of pollutants from North China Plain to surface ozone at the Shangdianzi GAW Station, Atmos. Chem. Phys., 8, 5889-5898, https://doi.org/10.5194/acp-8-5889-2008, 2008.

Lin, W., Xu, X., and Zhang, X.: Characteristics of gaseous pollutants at Gucheng, a rural site southwest of Beijing, J. Geophys. Res., 114, D00G14, https://doi.org/10.1029/2008JD010339, 2009.

Lin, W., Xu, X., Ge, B., and Liu, X.: Gaseous pollutants in Beijing urban area during the heating period 2007-2008: variability, sources, meteorological, and chemical impacts, Atmos. Chem. Phys., 11, 8157-8170, https://doi.org/10.5194/acp-118157-2011, 2011.

Lin, Y. C., Cheng, M. T., Ting, W. Y., and Yeh, C. R.: Characteristics of gaseous $\mathrm{HNO}_{2}, \mathrm{HNO}_{3}, \mathrm{NH}_{3}$ and particulate ammonium nitrate in an urban city of central Taiwan, Atmos. Environ., 40, 4725-4733, 2006.

Liu, M., Song, Y., Zhou, T., Xu, Z., Yan, C., Zheng, M., Wu, Z., Hu, M., Wu, Y., and Zhu, T.: Fine particle pH during severe haze episodes in northern China, Geophys. Res. Lett., 44, https://doi.org/10.1002/2017GL073210, 2017.

Liu, X. J., Zhang, Y., Han, W.X., Tang, A. H., Shen, J. L., Cui, Z. L., Peter, V., Jan, W. E., Keith, G., Peter, C., Andreas, F., and Zhang, F. S.: Enhanced nitrogen deposition over China, Nature, 28, 459-463, 2013.

Luo, X. S., Liu, P., Tang, A. H., Liu, J. Y., Zong, X. Y., Zhang, Q., Kou, C. L., Zhang, L. J., Fowler, D., Fangmeier, A., Christie, P., Zhang, F. S., and Liu, X. J.: An evaluation of atmospheric Nr pollution and deposition in North China after the Beijing Olympics, Atmos. Environ., 74, 209-216, 2013.

Makkonen, U., Virkkula, A., Mäntykenttä, J., Hakola, H., Keronen, P., Vakkari, V., and Aalto, P. P.: Semi-continuous gas and inorganic aerosol measurements at a Finnish urban site: comparisons with filters, nitrogen in aerosol and gas phases, and aerosol acidity, Atmos. Chem. Phys., 12, 5617-5631, https://doi.org/10.5194/acp-12-5617-2012, 2012.

Meng, Z. Y., Xu, X. B., Yan, P., Ding, G. A., Tang, J., Lin, W. L., Xu, X. D., and Wang, S. F.: Characteristics of trace gaseous pollutants at a regional background station in Northern China, Atmos. Chem. Phys., 9, 927-936, https://doi.org/10.5194/acp-9927-2009, 2009.
Meng, Z. Y., Lin, W. L., Jiang, X. M., Yan, P., Wang, Y., Zhang, Y. M., Jia, X. F., and Yu, X. L.: Characteristics of atmospheric ammonia over Beijing, China, Atmos. Chem. Phys., 11, 61396151, https://doi.org/10.5194/acp-11-6139-2011, 2011.

Meng, Z. Y., Zhang, R. J., Lin, W. L., Jia, X. F., Yu, X. M., Yu, X. L., and Wang, G. H.: Seasonal variation of ammonia and ammonium aerosol at a background station in the Yangtze River Delta Region, China, Aerosol Air Qual. Res., 3, 756-766, 2014.

Meng, Z. Y., Xie, Y. L., Jia, S. H., Zhang, R., Lin, W. L., Xu, X. B., and Yang, W.: The characteristics of atmospheric ammonia at Gucheng, a Rural Site in the North China Plain in summer 2013, J. Appl. Meteorol. Sci., 26, 141-150, 2015 (in Chinese).

Meng, Z. Y., Lin, W. L., Zhang, R. J., Han, Z. W., and Jia, X. F.: Summertime ambient ammonia and its effects on ammonium aerosol in urban Beijing, China, Sci. Total Environ., 579, 15211530, 2017.

Miao, Y., Guo, J., Liu, S., Liu, H., Li, Z., Zhang, W., and Zhai, P.: Classification of summertime synoptic patterns in Beijing and their associations with boundary layer structure affecting aerosol pollution, Atmos. Chem. Phys., 17, 3097-3110, https://doi.org/10.5194/acp-17-3097-2017, 2017.

Norman, M., Spirig, C., Wolff, V., Trebs, I., Flechard, C., Wisthaler, A., Schnitzhofer, R., Hansel, A., and Neftel, A.: Intercomparison of ammonia measurement techniques at an intensively managed grassland site (Oensingen, Switzerland), Atmos. Chem. Phys., 9, 2635-2645, https://doi.org/10.5194/acp-9-2635-2009, 2009.

Okuda, T.: Measurement of the specific surface area and particle size distribution of atmospheric aerosol reference materials, Atmos. Environ., 75, 1-5, 2013.

Park, R. S., Lee, S., Shin, S.-K., and Song, C. H.: Contribution of ammonium nitrate to aerosol optical depth and direct radiative forcing by aerosols over East Asia, Atmos. Chem. Phys., 14, 2185-2201, https://doi.org/10.5194/acp-14-2185-2014, 2014.

Pathak, R. K., Wu, W. S., and Wang, T.: Summertime $\mathrm{PM}_{2.5}$ ionic species in four major cities of China: nitrate formation in an ammonia-deficient atmosphere, Atmos. Chem. Phys., 9, 17111722, https://doi.org/10.5194/acp-9-1711-2009, 2009.

Plessow, K., Spindler, G., Zimmermann, F., and Matschullat, J.: Seasonal variations and interactions of $\mathrm{N}$-containing gases and particles over a coniferous forest, Saxony, Germany, Atmos. Environ., 39, 6995-7007, 2005.

Reche, C., Viana, M., Karanasiou, A., Cusack, M., Alastuey, A., Artiñano, B., Revuelta, M., López-Mahía, P., Blanco-Heras, G., Rodríguez, S., Sánchez de la Campa, A., Fernández- Camacho, R., González-Castanedo, Y., Mantilla, E., Tang, S., and Querol, X.: Urban $\mathrm{NH}_{3}$ levels and sources in six major Spanish cities, Chemosphere, 119, 769-777, 2015.

Reynold, C. M. and Wolf, D.: Effect of soil moisture and air relative humidity on ammonia volatilization from surface-applied urea, Soil Sci., 143, 144-152, 1987.

Robarge, W. P., Walker, J. T., McCulloch, R. B., and Murray, G.: Atmospheric concentrations of ammonia and ammonium at an agricultural site in the southeast United States, Atmos. Environ., 36, 16611-1674, 2002.

Roelle, P. A. and Aneja, V. P.: Characterization of ammonia emissions from soils in the upper coastal plain, North Carolina, Atmos. Environ., 36, 1087-1097, 2002.

Sauerwein, M. and Chan, C. K.: Heterogeneous uptake of ammonia and dimethylamine into sulfuric and oxalic acid particles, At- 
mos. Chem. Phys., 17, 6323-6339, https://doi.org/10.5194/acp17-6323-2017, 2017.

Schaap, M., Otjes, R. P., and Weijers, E. P.: Illustrating the benefit of using hourly monitoring data on secondary inorganic aerosol and its precursors for model evaluation, Atmos. Chem. Phys., 11, 11041-11053, https://doi.org/10.5194/acp-11-110412011, 2011.

Schwab, J. J.: Ambient Gaseous Ammonia: Evaluation of Continuous Measurement Methods Suitable for Routine Deployment, Final Report Prepared for the New York State Energy Research and Development Authority (NYSERDA)-Final Report 08-15, New York, October, 2008.

Seinfeld, J. H. and Pandis, S. N.: Atmospheric chemistry and physics: from air pollution to climate change, 2nd Edn., Wiley Interscience, New Jersey, 2006.

Shen, J. L., Liu, X. J., Zhang, Y., Fangmeier, A., Goulding, K., and Zhang, F. S.: Atmospheric ammonia and particulate ammonium from agricultural sources in the North China Plain, Atmos. Environ., 45, 5033-5041, 2011.

Sudheer, A. K. and Rengarajan, R.: Time-resolved inorganic chemical composition of fine aerosol and associated precursor gases over an urban environment in western India: gas-aerosol equilibrium characteristics, Atmos. Environ., 109, 217-227, 2015.

Tang, X., Zhang, X. S., Ci, Z. J., Guo, J., and Wang, J. Q.: Speciation of the major inorganic salts in atmospheric aerosols of Beijing, China: Measurements and comparison with model, Atmos. Environ., 133, 123-134, 2016.

Trebs, I., Meixner, F. X., Slanina, J., Otjes, R., Jongejan, P., and Andreae, M. O.: Real-time measurements of ammonia, acidic trace gases and water-soluble inorganic aerosol species at a rural site in the Amazon Basin, Atmos. Chem. Phys., 4, 967-987, https://doi.org/10.5194/acp-4-967-2004, 2004.

Walker, J. T., Whitall, D. R., Robarge, W., and Paerl, H. W.: Ambient ammonia and ammonium aerosol across a region of variable ammonia emission density, Atmos. Environ., 38, 1235-1246, 2004.

Walker, J. T., Robarge, W. P., Shendrikar, A., and Kimball, H.: Inorganic $\mathrm{PM}_{2.5}$ at a U.S. agricultural site, Environ. Pollut., 139, 258-271, 2006.

Wang, G., Zhang, R., Gomez, M. E., Yang, L., Zamora, M. L., Hu, M., Lin, Y., Peng, J., Guo, S., Meng, J., Li, J., Cheng, C., Hua, T., Ren, Y., Wang, Y., Gao, J., Cao, J., An, Z., Zhou, W., Li, G., Wang, J., Tian, P., Marrero-Ortiz, W., Secrest, J., Du, Z., Zheng, J., Shang, D., Zeng, L., Shao, M., Wang, W., Huang, Y., Wang, Y., Zhu, Y., Li, Y., Hu, J., Pan, B., Cai, L., Cheng, Y., Ji, Y., Zhang, F., Rosenfeld, D., Liss, P. S., Duce, R. B., Kolb, C. E, and Molina, M. J.: Persistent sulfate formation from London Fog to Chinese haze, P. Natl. Acad. Sci. USA, 113, 13630-13635, 2016.

Wang, S. S., Nan, J. L., Shi, C. Z., Fu, Q. Y., Gao, S., Wang, D. F., Cui, H. X., Alfonso, S. L., and Zhou, B.: Atmospheric ammonia and its impacts on regional air quality over the megacity of Shanghai, China. Sci. Rep., 5, 15842, https://doi.org/10.1038/srep15842, 2015.

Wang, T., Nie, W., Gao, J., Xue, L. K., Gao, X. M., Wang, X. F., Qiu, J., Poon, C. N., Meinardi, S., Blake, D., Wang, S. L., Ding, A. J., Chai, F. H., Zhang, Q. Z., and Wang, W. X.: Air quality during the 2008 Beijing Olympics: secondary pollutants and regional impact, Atmos. Chem. Phys., 10, 7603-7615, https://doi.org/10.5194/acp-10-7603-2010, 2010.
Wei, L. F., Duan, J. C., Tan, J. H., Ma, Y. L., He, K. B., Wang, S. X., Huang, X. F., and Zhang, Y. X.: Gas-to-particle conversion of atmospheric ammonia and sampling artifacts of ammonia in spring of Beijing, Sci. China Earth Sci., 58, 345-355, 2015.

Xu, P., Zhang, Y., Gong, W., Hou, X., Kroeze, C., Gao, W., and Luan, S.: An inventory of the emission of ammonia from agricultural fertilizer application in China for 2010 and its highresolution spatial distribution, Atmos. Environ., 115, 141-148, 2015.

Xu, P., Liao, Y. J., Lin, Y. H., Zhao, C. X., Yan, C. H., Cao, M. N., Wang, G. S., and Luan, S. J.: High-resolution inventory of ammonia emissions from agricultural fertilizer in China from 1978 to 2008, Atmos. Chem. Phys., 16, 1207-1218, https://doi.org/10.5194/acp-16-1207-2016, 2016.

Xu, W., Song, W., Zhang, Y., Liu, X., Zhang, L., Zhao, Y., Liu, D., Tang, A., Yang, D., Wang, D., Wen, Z., Pan, Y., Fowler, D., Collett Jr., J. L., Erisman, J. W., Goulding, K., Li, Y., and Zhang, F.: Air quality improvement in a megacity: implications from 2015 Beijing Parade Blue pollution control actions, Atmos. Chem. Phys., 17, 31-46, https://doi.org/10.5194/acp-17-31-2017, 2017.

Xue, L. K., Wang, T., Gao, J., Ding, A. J., Zhou, X. H., Blake, D. R., Wang, X. F., Saunders, S. M., Fan, S. J., Zuo, H. C., Zhang, Q. Z., and Wang, W. X.: Ground-level ozone in four Chinese cities: precursors, regional transport and heterogeneous processes, Atmos. Chem. Phys., 14, 13175-13188, https://doi.org/10.5194/acp-1413175-2014, 2014.

Yao, X. H., Chak, K. C., Fang, M., Cadle, S., Chan, T., Mulawa, P., He, K. B., and Ye, B. M.: The water-soluble ionic composition of $\mathrm{PM}_{2.5}$ in Shanghai and Beijing, China, Atmos. Environ., 36, 4223-4234, 2002.

Yao, X. H., Ling, T. Y., Fang, M., and Chan, C. K.: Comparison of thermodynamic predictions for in situ $\mathrm{pH}$ in $\mathrm{PM}_{2.5}$, Atmos. Environ. 40, 2835-2844, 2006.

Ye, X. N., Ma, Z., Zhang, J.C., Du, H. H., Chen, J. M., Chen, H., Yang, X., Gao, W., and Geng, F. H.: Important role of ammonia on haze formation in Shanghai, Environ. Res. Lett., 6, 024019, https://doi.org/10.1088/1748-9326/6/2/024019, 2011.

Zhang, T., Cao, J., Tie, X., Shen, Z., Liu, S., Ding, H., Han, Y., Wang, G., Ho, K., Qiang, J., and Li, W.: Water-soluble ions in atmospheric aerosols measured in Xi' an, China: Seasonal variations and sources, Atmos. Res., 102, 110-119, 2011.

Zhang, Y., Dore, A. J., Ma, L., Liu, X. J., Ma, W. Q., Cape, J. N., and Zhang, F. S.: Agricultural ammonia emissions inventory and spatial distribution in the North China Plain, Environ. Pollut., 158, 490-501, 2010.

Zhou, Y., Wang, T., Gao, X. M., Xue, L. K., Wang, X. F., Wang, Z., Gao, J., Zhang, Q. Z., and Wang, W. X.: Continuous observations of water-soluble ions in $\mathrm{PM}_{2.5}$ at Mount Tai (1534 m a.s.1.) in central-eastern China, J. Atmos. Chem., 64, 107-127, 2009.

Zhou, Y., Cheng, S., Lang, J., Chen, D., Zhao, B., Liu, C., Xu, R., and $\mathrm{Li}$, T.: A comprehensive ammonia emission inventory with high-resolution and its evaluation in the Beijing-Tianjin-Hebei (BTH) region, China, Atmos. Environ., 106, 305-317, 2015. 